\title{
The Effect of Melatonin or Maternal Nutrient Restriction on Cell Proliferation in the Ovine Placenta
}

\author{
Adam Walter Eifert \\ West Virginia University
}

Follow this and additional works at: https://researchrepository.wvu.edu/etd

\section{Recommended Citation}

Eifert, Adam Walter, "The Effect of Melatonin or Maternal Nutrient Restriction on Cell Proliferation in the Ovine Placenta" (2013). Graduate Theses, Dissertations, and Problem Reports. 3609.

https://researchrepository.wvu.edu/etd/3609

This Thesis is protected by copyright and/or related rights. It has been brought to you by the The Research Repository @ WVU with permission from the rights-holder(s). You are free to use this Thesis in any way that is permitted by the copyright and related rights legislation that applies to your use. For other uses you must obtain permission from the rights-holder(s) directly, unless additional rights are indicated by a Creative Commons license in the record and/ or on the work itself. This Thesis has been accepted for inclusion in WVU Graduate Theses, Dissertations, and Problem Reports collection by an authorized administrator of The Research Repository @ WVU. For more information, please contact researchrepository@mail.wvu.edu. 
The Effect of Melatonin or Maternal Nutrient Restriction on Cell Proliferation in the Ovine Placenta

Adam Walter Eifert

Thesis submitted to the Davis College of Agriculture, Forestry and Consumer Sciences at West Virginia University in partial fulfillment of the requirements for the degree of

\author{
Master of Science \\ in \\ Reproductive Physiology \\ Matthew E. Wilson, Ph.D., Chair \\ Caleb O. Lemley, Ph.D. \\ Jianbo Yao, Ph.D.
}

Division of Animal and Nutritional Sciences

Morgantown, WV

2013

Keywords: Fetal Development, Gestational Nutrition, Melatonin 


\section{ABSTRACT \\ The Effect of Melatonin or Maternal Nutrient Restriction on Cell Proliferation in the Ovine Placenta}

\section{Adam W. Eifert}

Our objectives were to assess melatonin receptor dependent modulation of placental cell proliferation following treatment with either melatonin, luzindole (melatonin receptor 1 and 2 antagonist), or vehicle. In addition, a second study was conducted to assess placental cell proliferation following dietary melatonin treatment in a maternal nutrient restriction model. For the first experiment, 14 primiparous ewes were fitted with Alzet mini osmotic pumps attached to a catheter and infused with vehicle, melatonin, or luzindole from d 62 to 90 of gestation. Ewes were euthanized and placentomes collected for analysis at the end of the 4 week infusion. For the second experiment, 31 primiparous ewes were supplemented with $5 \mathrm{mg}$ of melatonin per d (MEL) or no melatonin (CON) and allocated to receive 100\% (adequate) or 60\% (restricted) of their nutrient requirements from d 50 to 130 of gestation. On d 130 of gestation, ewes were euthanized and placentomes were collected for analysis. Placentomes from both experiment 1 and 2 were examined for percentage of proliferating cells using an immunofluorescence assay. A $\mathrm{Ki}-67$ mouse monoclonal antibody was used to stain proliferating cells within each tissue section and was compared to non-proliferating cells stained with DAPI to determine the percentage of proliferating cells within each sample. Total RNA, DNA and protein was also analyzed within each sample. For experiment 1, cell proliferation in the cotyledon and caruncle was not affected $(P>0.30)$ by vehicle, melatonin or luzindole infusions. Dietary melatonin supplementation from mid to late gestation may impact cotyledon cell proliferation; however chronic infusion of melatonin or luzindole did not change proliferation in either the cotyledon or caruncle. Treatment did not alter the concentrations of RNA, DNA, protein $(\mathrm{P} \geq 0.15)$, or the ratio of RNA:DNA and the ratio of protein:DNA ( $\mathrm{P} \geq 0.17$ ). For experiment 2 , there was no melatonin supplementation by nutritional plane interactions $(P>0.50)$ on cellular proliferation in either the cotyledon or caruncle. There was a tendency $(P=0.08)$ for melatonin supplemented ewes to have an increased percentage of proliferating cells in the cotyledon; however, this effect of melatonin was absent $(P>0.30)$ in the caruncle. Nutritional plane did not alter cellular proliferation in either the cotyledon $(P>0.70)$ or caruncle $(P>0.50)$. There was no effect of nutritional plane or melatonin treatment on the concentration of DNA or protein $(\mathrm{P} \geq 0.21)$ in caruncular tissue. However there was an interaction on RNA $(\mathrm{P}=0.02)$ in caruncular tissue which may be due to an increase in gene expression following melatonin treatment. There was no effect of treatment or nutritional plane on DNA, RNA, protein $(\mathrm{P} \geq 0.20)$ as well as no effect on RNA:DNA or protein:DNA $(\mathrm{P} \geq 0.25)$. In summary, melatonin may alter placental growth in ewes with IUGR; however, this needs further investigation. 


\section{TABLE OF CONTENTS}

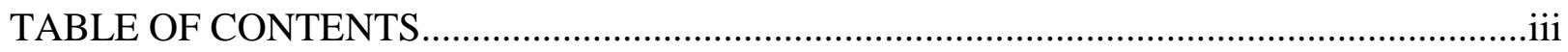

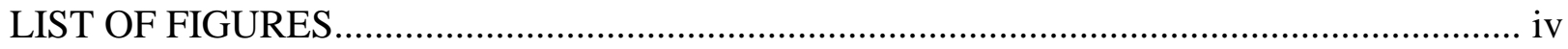

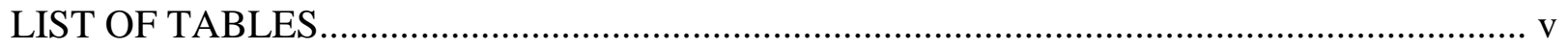

ACKNOWLEDGEMENTS............................................................................................

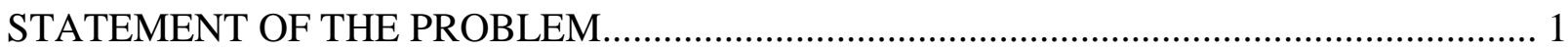

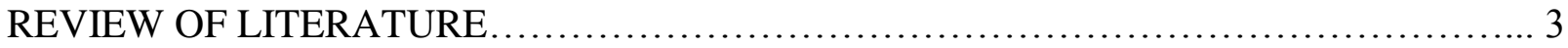

MELATONIN BIOSYNTHESIS ............................................ 3

METABOLIC CLEARANCE OF MELATONIN ...................................7

REGULATION OF MELATONIN ............................................ 5

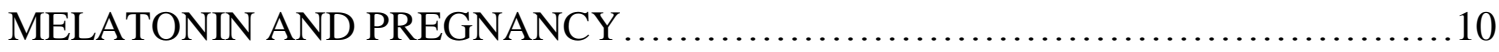

NUTRITIONAL REQUIREMENTS DURING GESTATION .......................13

THE EFFECT OF MELATONIN OR MATERNAL NUTRIENT RESTRICTION ON CELL PROLIFERATION IN THE OVINE PLACENTA

INTRODUCTION.............................................................. 17

MATERIALS AND METHODS ................................................ 18

ANIMAL MANAGEMENT FOR INFUSION STUDY .......................18

SURGERIES FOR INFUSION STUDY ...................................19

TISSUE COLLECTION FOR INFUSION STUDY ........................20

ANIMALS AND TREATMENT FOR DIETARY STUDY .....................20

NUTRITIONAL SUPPLEMENTATION FOR DIETARY STUDY ..............21

TISSUE COLLECTION FOR DIETARY STUDY ........................... 22

MEASUREMENT OF PLACENTOME CELLULAR PROLIFERATION.......22

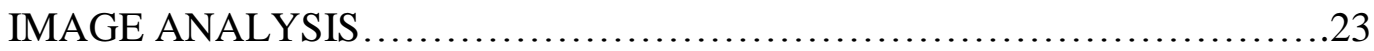

CELLULARITY ESTIMATES (DNA, RNA, TOTAL PROTEIN)............... 24

STATISTICAL ANALYSIS ................................................ 25

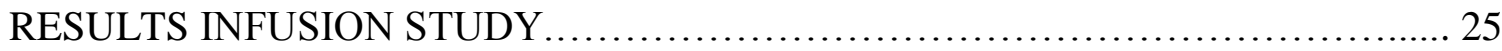

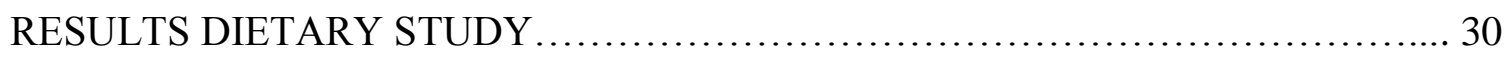

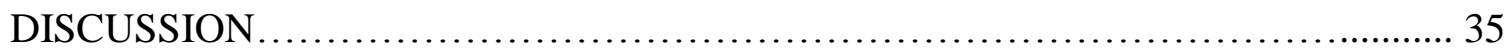

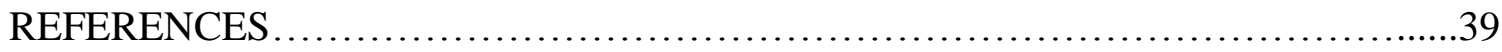




\section{LIST OF FIGURES}

Figure 1: Cellular proliferation based on percent KI-67 positive cells at day 90 of gestation from ewes chronically infused with luzindole (LUZ), vehicle control (CON), or melatonin (MEL) beginning on day 62 of gestation.

Figure 2: Cellular proliferation based on percent KI-67 positive cells at day 130 of gestation from ewes supplemented with $5 \mathrm{mg}$ of melatonin (MEL) or no melatonin (CON) and provided $100 \%$ (ADQ; adequate diet) or $60 \%$ (RES; restricted diet) of nutrient recommendations beginning on day 50 of gestation. 


\section{LIST OF TABLES}

Table 1: Ewe body weight, placental size, fetal size, and uteroplacental blood flow at day 90 of gestation from ewes chronically infused with luzindole (LUZ), vehicle control (CON), or melatonin (MEL) beginning on day 62 of gestation. Data adapted from Lemley et al. (2013).

Table 2: Placental measures of DNA, RNA, protein, and cellular proliferation at day 90 of gestation from ewes chronically infused with luzindole (LUZ), vehicle control (CON), or melatonin (MEL) beginning on day 62 of gestation.

Table 3: Ewe body weight, placental size, fetal size, and uteroplacental blood flow at day 130 of gestation from ewes supplemented with $5 \mathrm{mg}$ of melatonin (MEL) or no melatonin (CON) and provided $100 \%$ (ADQ; adequate diet) or 60\% (RES; restricted diet) of nutrient recommendations beginning on day 50 of gestation. Data adapted from Lemley et al. (2012).

Table 4: Placental measures of DNA, RNA, protein, and cellular proliferation at day 130 of gestation from ewes supplemented with $5 \mathrm{mg}$ of melatonin (MEL) or no melatonin (CON) and provided $100 \%$ (ADQ; adequate diet) or 60\% (RES; restricted diet) of nutrient recommendations beginning on day 50 of gestation. 


\section{ACKNOWLEDGEMENTS}

Firstly, I would like to thank my advisor Dr. Wilson for the guidance and support he has given me over the past several years as both an undergraduate and graduate student at West Virginia University. I would also like to thank Caleb Lemley for always being there to answer any question I may have had in the area of my research to help me better understand the intricacies of reproductive physiology. Additionally, I would like to thank the faculty and graduate students in the animal science department at North Dakota State University for the help they provided me during my short stay there, I do not know how I would have completed everything on schedule without them. On a more personal note, I would like to thank my friends and family for giving me the support and motivation I needed to get through some of the long days, both in the lab and office, I am truly grateful. Finally, and most importantly, I would like to my girlfriend Brenda Shibley for giving me the strength and support I have needed over the years, you have been with me through it all and hopefully this is just the beginning. Thank you for your love, friendship, and patience, I will be forever grateful. 


\section{STATEMENT OF THE PROBLEM}

During the neonatal period, offspring with low birth weight have a higher incidence of morbidity and mortality, while surviving offspring with low birth weight have lower rates of gross energy accretion and poor growth rates (Barker and Clark 1997; Greenwood et al. 1998). When birth weights are below average, lamb mortality rates can be as high as 20 to $50 \%$, which can be detrimental to the producer (Mukasa-Mugerwa et al. 1994). Lamb survivability can be associated with several factors and, when birth weights are low, total lamb loss rate can be as high as $5 \%$. As of 2013, the total sheep and lamb inventory in the United States is estimated to be approximately 5.34 million with an annual loss of 267,000 lambs due to low birth weight (NASS, 2013). Assuming 30 to 40 pounds of meat harvested per lamb, we could estimate an annual loss of over 10 million pounds of meat due to low birth weight which amounts to millions of dollars in lost revenue. If the amount of offspring with low birth weight could be reduced, we could increase production, revenue and amount of meat available for consumption, which is not only important for farmers in the U.S., but also important for developing countries that rely on sheep as a source of protein.

Melatonin is produced in the pineal gland located near the hypothalamus in the brain and is involved in regulating several physiological processes including reproduction, sleep, energy balance and behavior in a variety of species (Almeida et al. 2011). Melatonin is unique in that it is one of the few hormones that is able to cross the placenta and be delivered to the fetus unaltered (Torres-Farfan et al. 2008). Studies have shown that melatonin supplementation has been associated with decreasing uterine contractility in the rat, stimulating the secretion of progesterone (Forcada et al. 2006), increasing the release of gonadotropins from the pituitary in the ewe (Aleandri et al. 2006), and removal of the pineal gland in pregnant rats has been linked 
to an elevated incidence of spontaneous abortions (Sandyk et al. 1992).Currently, very little research has been conducted on melatonin supplementation and its effects on increasing birth weight and uteroplacental blood flow. If melatonin supplementation proves to be effective in increasing both of these, it could be used to rescue compromised pregnancies and subsequently reduce fetal mortality. Our objectives were to determine the effect of melatonin supplementation, either through the diet or chronic infusion, on cellular proliferation in the placentome as well as its effect on the concentration of RNA, DNA and protein in intra-uterine growth restriction (IUGR) pregnancies. 


\section{REVIEW OF LITERATURE}

\section{Melatonin Biosynthesis}

Production of melatonin by the pineal gland, located near the hypothalamus in the brain, has several important physiological roles including regulating sleep, reproduction, molting, immune responses, energy balance, and behavior within a broad range of species (Almeida et al. 2011). Deficiencies in pineal secretion that cause a reduction in melatonin production can be associated with insomnia, anxiety, elevated estrogen/progesterone ratio, and immune suppression (Arendt 1998). The biosynthesis pathway for the production of melatonin was adapted from Voet and Voet (2004). The first step in the biosynthesis of melatonin is hydroxylation of tryptophan by tryptophan hydroxylase to 5-hydroxytryptophan which requires tetrahydrobiopterine as a cofactor. Decarboxylation of 5-hydroxytryptophan by 5-hydroxytryptophan decarboxylase produces serotonin. Serotonin, with the use of acetyl-coA, is converted to $\mathrm{N}$-acetyl-serotonin by serotonin acetyltransferase. The final step is the conversion of $\mathrm{N}$-acetyl-serotonin to melatonin by 5-hydroxyindole-O-methyltransferase (HIOMT), which is the rate limiting step in melatonin synthesis. HIOMT is known as the "melatonin rhythm enzyme" since it plays a time keeping role between environmental signals and the production and release of melatonin (Ganguly et al. 2002). 


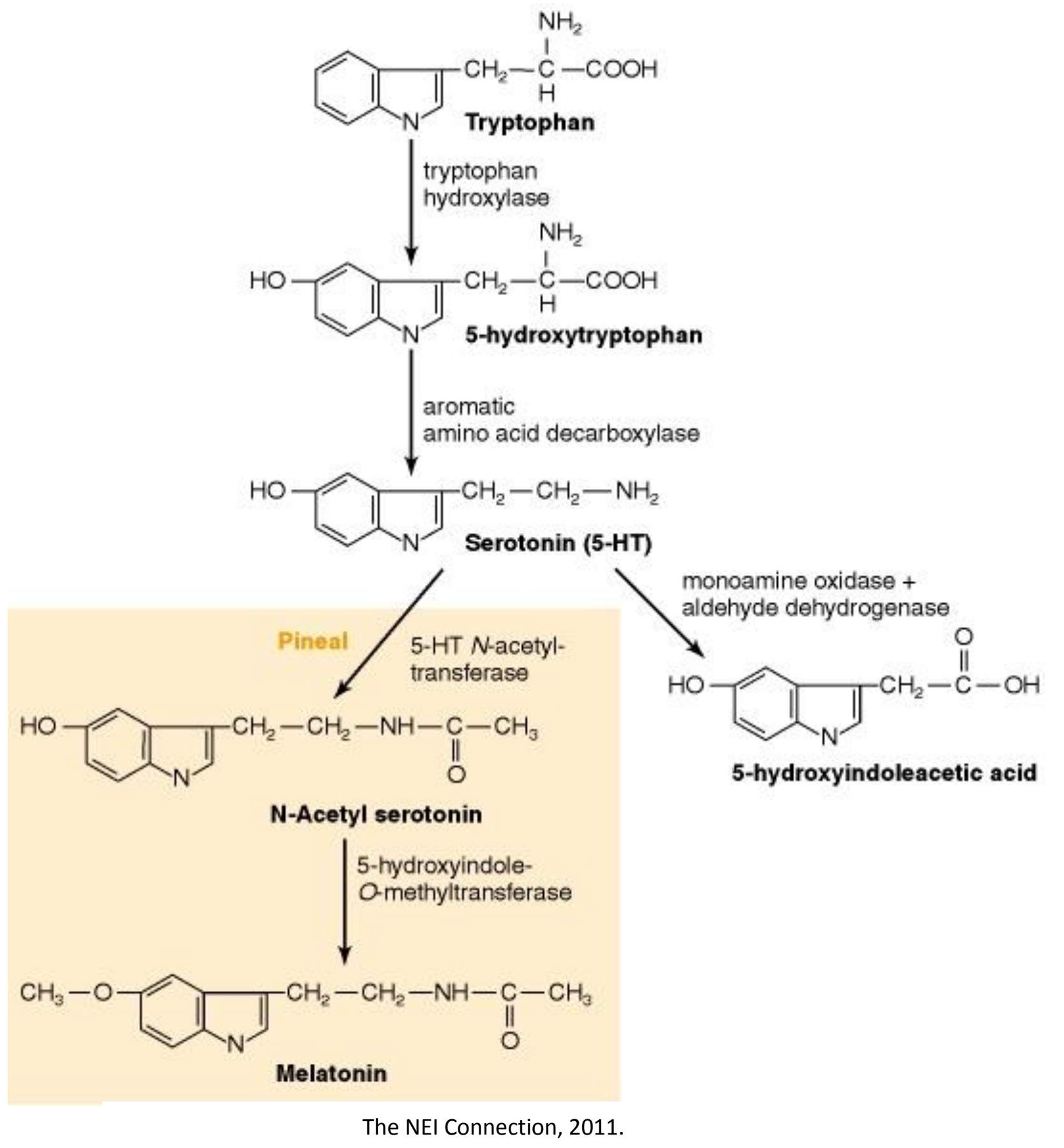

Melatonin levels in ovine plasma are low during the photophase and usually begin to increase at the start of the scotophase and peak between midnight and 3:00 hours followed by a rapid decrease in concentration (Yellon and Longo 1987; Ganguly et al. 2002). However, the 
timing for the rise in melatonin concentration is dependent on the season (i.e. short days vs. long days) when the start of the scotophase occurs. Plasma concentrations of melatonin have been found to be highly variable among individuals of the same species and may be under strong genetic control (Zarazaga et al. 1998). A study conducted by Zarazaga et al. (1998) examined the average concentrations of melatonin in the blood plasma of sheep during both short (December) and long (June) days. They found that during short days mean nocturnal plasma melatonin concentrations were $400.4 \mathrm{pg} / \mathrm{mL}$ compared to long days having a mean concentration of 328.3 $\mathrm{pg} / \mathrm{mL}$ although it was highly variable among individuals. A similar study conducted by Coon et al. (1999) placed lambs in groups of either high or low genetic value based on endogenous nocturnal plasma melatonin concentration of their parents. They found that mean nocturnal plasma melatonin concentrations varied significantly among lambs with a high genetic value (344.1 pg/mL) compared to lambs with a low genetic value $(189.7 \mathrm{pg} / \mathrm{mL})$. This study indicated that nocturnal melatonin concentrations are under genetic control.

\section{Metabolic Clearance of Melatonin}

Upon synthesis, melatonin is immediately released into circulation and is found in circulation within a very short period (Pandi-Perumal et al. 2006). Zarazaga et al. (1998) found that melatonin to be ten-fold higher in the blood plasma compared with saliva and concentrations in the third ventricle are 20-30 times higher than that found in the blood. A study done by Calustrat et al. (2005) found the half life of melatonin to be bi-exponential with a first distribution half-life of two minutes followed by the second of 20 minutes. Keveder and McIssac (1961) found that the majority of melatonin (70\%) is cleared by the kidneys while the remaining $30 \%$ is excreted in the feces. 
The catabolism of melatonin occurs primarily in the liver and is first hydroxylated in the C6 position by cytochrome $\mathrm{P}_{450}$ mono-oxygenases specifically CYP1A1, CYP1A2, CYP1B1, and CYP2C19 (Ma et al. 2005; Pandi-Perumal et al. 2006). After hydroxylation the product, 6hydroxymelatonin, is conjugated with sulfate and is excreted in the urine as 6sulfatoxymelatonin (aMT6S) (Claustrat et al. 2005). Melatonin can also be demethylated by CYP1A2 to N-acetylserotonin, which is the precursor to melatonin in the synthesis pathway (Pandi-Perumal et al. 2006). Ma et al. (2005) studied the metabolism of melatonin by human cytochrome $\mathrm{P}_{450}$, and found that CYP1A2 and CYP2C19 were mainly responsible for the hepatic clearance of melatonin from blood plasma. They also found that CYP1B1 was not expressed in high levels within the liver but has a more wide spread distribution in extra-hepatic tissues indicating its role in the 6-hydroxylation of melatonin outside the liver (Ma et al. 2005). Secondary sites of melatonin metabolism vary depending on the tissue in which it is located. Organs derived from neural tissues such as the pineal gland and the retina contain melatonindeacetylating enzymes (Pandi-Perumal et al. 2006). These enzymes can either be specific for melatonin deacetylases or aryl acylamidases which are less specific (Hardeland et al. 1996). Melatonin can be deacetylated to 5-methoxytryptamine in any tissue containing serine-sensitive acetylcholinesterase due to its aryl acylamidase side activity (Hardeland et al. 1993; Hardeland et al. 1996). Not only can melatonin be catabolized by specific enzymes, but it can also be broken down non-enzymatically both intra and extra-cellularly by free radicals and antioxidants (PandiPerumal et al. 2006). The non-enzymatic metabolism of melatonin is achieved by hydroxylation using two hydroxyl radicals, which converts melatonin into 3-hydroxymelatonin and is removed from the body through the urine (Tan et al. 1998). In the brain a large portion of melatonin is metabolized to kynuramine derivatives specifically $\mathrm{N}^{1}$-acetyl- $\mathrm{N}^{2}$-formyl-5-methyoxykynuramine 
(AMFK) (Hirata et al. 1974; Pandi-Perumal et al. 2006). Arylamine formidase or hemoperoxidases then deformylates AMFK to $\mathrm{N}^{1}$-acetyl-5-methoxykynuramine (AMK) and recent studies have found that this reaction contributes to about $1 / 3$ of the total catabolism of melatonin (Hardeland et al. 2006). Silva et al. (2004) found that the metabolism of melatonin to AMFK played an important role in the innate immune response by inhibiting the release of proinflammatory cytokines, specifically interlukin-8 (IL-8), and tumor necrosis factor-alpha (TNFa) from neutrophils which are known to cause inflammation.

\section{Regulation of Melatonin}

The regulation of melatonin involves several mechanisms that are in turn regulated by the exposure to light (Karsh et al. 1991; Arendt 1995). The suprachiasmatic nucleus (SCN) is the bodies' circadian oscillator and is part of the photoneuroendocrine system. The circadian rhythm is controlled by the circadian oscillator that generates a rhythm which repeats roughly every 24 hours (Moore and Klein 1974; Klein and Moore 1979; Reppert et al. 1981). There are two main systems that control the signals sent to the SCN. The first appears to be classic rods and cones located within the retina of the eye (Bronstein et al. 1987; Nelson and Takahashi 1991). The second system is comprised of melanopsin-positive retinal ganglion (MPRG) cells (Ganguly et al. 2002). These specialized cells are a specific type of photoreceptors located in the ganglion cell layer of the retina (Ganguly et al. 2002). Information on day light, perceived from the rods and cones, is delivered to the MPRG cells which directly innervate the SCN which either causes an increase or decrease in aralkylamine- $\mathrm{N}$-acetyltransferase (AANAT) activity depending on the current light conditions leading to an increased production of melatonin when AANAT levels are high (Ganguly et al. 2002). Light can either have a stimulatory or inhibitory effect on melatonin 
synthesis. The stimulatory effects of light increase AANAT activity and melatonin synthesis while the inhibitory effects of light interrupt the transmission of signals sent from the SCN to the pineal gland decreasing AANAT activity and melatonin synthesis (Klein and Weller 1972; Klein 1985; Ganguly et al. 2002).

The melatonin rhythm generating system involves a complex pathway where signals are sent from the retina to locations within the brain. As light conditions are registered by the retina, the MPRG cells in cooperation with rods and cones send signals to the SCN on the current perceived lighting conditions (Ganguly et al. 2002). This information is then sent to the paraventricular nucleus (PVN) which is innervated by cells from the SCN (Kalsbeek and Bujis 2002). Cells in the PVN innervate the "medial forebrain bundle and reticular formation to preganglionic cells in the intermediolateral cell column of the spinal cord" (Ganguly et al 2002). The signal is then sent to the superior cervical ganglia and transferred to the pineal gland by the inferior carotid nerve and nervi conarii (Ganguly et al 2002). The pineal gland contains norepinephrine (NE) containing fibers which are stimulated by the signals received from the inferior carotid nerve and nervi conarii (Sugden et al. 1985; Vanecek et al. 1985). When stimulated these NE containing fibers release NE that binds to $\alpha_{1}$ and $\beta_{1}$ adrenergic receptors (AR) of the pinealocyte (Sugden et al. 1985; Vanecek et al. 1985). The binding of NE to $\beta_{1}$-AR receptors results in the production of adenylate cyclase through the Gs pathway (Ganguly et al 2002). Norepinephrine binding to the $\alpha_{1}$-adernergic receptors increases intracellular calcium levels as well as stimulating the production of diacylglycerol (DAG) activating protein kinase C (PKC; Sugden and Klein 1988). Adenylate cyclase in cooperation with PKC increases the production of the second messenger cyclic AMP (Sugden et al. 1985). Cyclic AMP, through several intracellular mechanisms, increases the activity of AANAT within the pinealocyte 
(Ganguly et al. 2002; Yu et al. 1993). The increased activity of AANAT significantly enhances the conversion of serotonin (5-hydroxytryptamine) to $\mathrm{N}$-acetyl-serotonin which is then converted to melatonin by hydroxyindole-o-methyltransferase (Ganguly et al. 2002). The newly synthesized melatonin is immediately released into circulation, and the amount released is controlled by the pineal gland (Illnerova et al 1978). As the nocturnal period ends, neural stimulation begins to decrease leading to a reduction in cyclic AMP and subsequently a reduction in the activity of HIOMT returning circulating melatonin levels back to a diurnal state (Ganguly et al. 2002).

The amphibian melatonin receptor was first cloned in 1994 followed by the human and sheep receptor soon after (Arendt 1995). The activity of melatonin receptors fluctuate throughout the day depending on light conditions and is based upon the circulating levels of melatonin (Witt-Enderby et al. 2003). Signal transduction cascades can either be activated or inhibited by melatonin which acts either directly through its receptor or independently (Witt-Enderby et al 2003). Melatonin can act independently from its receptor due to its lipophillic nature and/or due to an active uptake mechanism (Benitez-King and Anton-Tay 1993; Finocchiaro and Gilkin 1998; Mendez-Pelaez and Reiter 1993). There are three main receptor subtypes which melatonin can bind to and activate. The $\mathrm{MT}_{1}$ and $\mathrm{MT}_{2}$ receptors are G-protein coupled receptors while the $\mathrm{MT}_{3}$ receptor belongs to a family of quinine reductases (Witt-Enderby et al. 2003). $\mathrm{The}^{\mathrm{MT}} \mathrm{T}_{1}$ receptor is expressed in the $\mathrm{SCN}$ of the hypothalamus as well as cardiac vessels and is involved in regulating circadian rhythm and constricting blood vessels (Dubocovich et al. 1998; Liu et al. 1997). It has also been found to be expressed in other regions of the brain and peripheral tissues throughout the body, although its actions here are not fully understood (Witt-Enderby 2003). Not only can $\mathrm{MT}_{1}$ receptors bind melatonin but they can also bind a wide variety of G-proteins 
eliciting various responses throughout the body (Brydon et al. 1999; Chan et al. 2002). Several studies have shown that $\mathrm{MT}_{1}$ receptors decrease the activity of PKA due to inhibitory responses on the cAMP signal transduction cascade as well as decreasing CREB phosphorylation, which are both involved in the melatonin synthesis pathway (Ganguly et al, 2002; Witt-Enderby et al. 2003). The $\mathrm{MT}_{2}$ receptor, like the $\mathrm{MT}_{1}$ receptor is involved in regulating circadian rhythm and dilating cardiac vessels as well as being involved in retinal physiology and inflammatory responses (Dubocovich et al. 1997; Sugden et al. 1999). The $\mathrm{MT}_{2}$ receptor is not as widely dispersed as the $\mathrm{MT}_{1}$ receptor and is expressed in the SCN, retina, kidneys, ovaries, and cardiac vessels as well as the sheep placenta (Witt-Enderby et al. 2003; Lemley et al. 2012). The $\mathrm{MT}_{3}$ receptor is unique in that it displays a binding pattern similar to that of the $\mathrm{MT}_{2}$ receptor (Dubocovich 1995). It was recently affinity-purified from the Syrian hamster kidney and has been found to share a 95\% homology to the quinine-reductase 2 enzyme (Nosjean et al. 2000). This protein has been found to be expressed in the heart, brain, kidney, liver, lungs, intestines, spleen, testis, skeletal muscle, and brown adipose tissue of the mouse, dog, monkey, and hamster (Nosjean et al. 2001).

\section{Melatonin and Pregnancy}

Melatonin is unique in that it is one of the few maternal hormones that is able to cross the placenta unaltered (Torres-Farfan et al. 2008). During prenatal development the fetal pineal gland is not capable of synthesizing melatonin and relies on maternal production for the supply of this hormone even though the enzymes responsible for synthesizing indoles are active before birth (Torres-Farfan et al. 2008; Kennaway et al. 1977). A study conducted by Tamarkin et al. (1980) examined the post-natal maturation of pineal innervation in hamsters and found that it 
coincides with the development of nocturnal rhythm of melatonin release around the second week of life. Another study conducted by Klein and Lines (1969) found that in the rat, melatonin rhythm is dependent on both the innervation of the pineal gland as well as the presence of the enzymes responsible for the synthesis of melatonin. In sheep, nycthemeral release of melatonin is not present until the tenth week of postnatal life which may be due to the incomplete sympathetic innervation of the pineal gland prenatally (Tamarkin et al. 1980; Yellon and Longo 1987). Circulating levels of melatonin in the fetus displays a diurnal rhythm that is directly related to the maternal release of melatonin; low levels during the day leading to a several fold increase during the night (Yellon and Longo 1988; Weaver and Reppert 1986). This pattern of secretion relays information on day length and circadian rhythm to the fetus and plays an essential role in synchronizing the developing circadian nervous system to the time of day based on light conditions (Reppert 1985; Reppert et al. 1987). Yellon and Longo (1987) looked at melatonin rhythm in both the mother and fetus during the last trimester of gestation in sheep. They found that at day 120 of pregnancy, circulating concentrations of melatonin were present in all pregnant sheep and was similar to the circulating levels in non-pregnant ewes. They also reported that fetal concentrations of melatonin were higher during the day (36 pg/ml) compared to maternal circulating levels $(22 \mathrm{pg} / \mathrm{ml})$ and remained this way through day 135 of gestation. These data indicate that there is a 24-hour pattern of circulating melatonin in the fetus. A similar study conducted by Yellon and Longo (1988) concluded that the 24-hour pattern of melatonin in the fetus during the last trimester was directly related to the circadian release of melatonin from the maternal pineal gland due to undetectable concentrations of melatonin in the fetus after maternal pinealectomy. 
Melatonin can be detected in essentially every compartment throughout the body including the human preovulatory follicle, and placenta, and may also be synthesized in the ovary due to the presence of AANAT and HIOMT, key enzymes involved in the synthesis of melatonin (Tamura et al. 2009). Several studies have shown that granulosa cell steroidogenesis and follicular function are altered by melatonin in the hen, hamster, and in humans (Tamura et al. 2009). The melatonin receptors, $\mathrm{MT}_{1}$ and $\mathrm{MT}_{2}$, have been identified in human granulosa and luteal cells, human and sheep placenta, and also in rat ovaries (Soares et al. 2003; Yie et al. 1995, Lemley et al. 2012). In the ewe, long term administration of melatonin has been found to have a stimulatory affect on the hypothalamic-pituitary-ovarian-axis (HPO) by increasing pulsatile luteinizing hormone releasing hormone (LHRH) and luteinizing hormone (LH) release from both the hypothalamus and pituitary glands respectively (Aleandri et al. 1996). Woo et al. (2001) found that melatonin modifies luteal function and also increases mRNA expression of the $\mathrm{LH}$ receptor in human luteal cells. This response could be attributed to antioxidant properties of melatonin protecting the corpus luteum (CL) from reactive oxygen species (Tamura et al. 2009). Preventing the regression of the CL would allow production of progesterone during the luteal phase and early pregnancy (Tamura et al. 2009). Bittman et al. (1985) found that the pulsatile secretion of LH is mediated by melatonin which controls estradiol negative feedback on the hypothalamus. Prostaglandin- $\mathrm{F}_{2 \alpha}\left(\mathrm{PGF}_{2 \alpha}\right)$ is the key hormone responsible for luteolysis and suppression of progesterone production. Deng et al. (2006) treated a murine macrophage cell line with supra-physiological concentrations $(0.1-1 \mathrm{mM})$ of melatonin and found that the treatment inhibited COX-2 gene expression which is the enzyme responsible for the synthesis of $\mathrm{PGF}_{2 \alpha}$. Maintaining the CL until placental takeover in the sheep, by inhibiting the factors which lead to 
its regression, is essential for the continued production of progesterone which is necessary for a successful pregnancy.

\section{Nutritional Requirements During Gestation}

Following conception, the fertilized egg goes through several developmental stages before becoming a blastocyst around day 7 in the ewe (Senger 2003). Approximately 7-8 days following fertilization, the blastocyst "hatches" becoming a free floating embryo within the lumen of the uterus (Senger 2003). At this time, the ovine embryo produces interferon tau which signals for the maternal recognition of pregnancy and the continued production of progesterone by the corpus luteum to maintain pregnancy. Before the rapidly growing embryo can attach to the uterine epithelium, placentation must occur. Ruminants, such as the ewe, have an epitheliolchorial placenta that is compromised of 60-100 unique structures known as placentomes (Reynolds et al. 2005). The placentome is the location of nutrient and gas exchange between the mother and fetus throughout gestation. The maternal portion of these structures, known as caruncles, are present shortly after birth and their number and location remain constant throughout the lifespan of the dam (Reynolds et al. 2005). During early gestation the fetal portion of the placentome, the cotyledon, develops from the chorion and attaches to the caruncle approximately 15-18 days after ovulation (Senger 2003). Placental growth in terms of mass occurs during the first two thirds of gestation and placentomes reach their maximum size and weight around day 90 of gestation, while $90 \%$ of fetal growth occurs during the last third of pregnancy (Sammin et al. 2009; Redmer et al. 2004).

Adequate maternal nutrition during gestation is essential for the proper growth and survival of the developing conceptus. The placenta is responsible for transferring nutrients to the 
fetus which can be altered due to the size and nutrient transfer capacity of the placenta (Redmer et al. 2004). The nutrient exchange system between the dam and the fetus is dependent on both the uterine and umbilical blood flow which is in turn dependent on the adequate vascularization of the placenta (Redmer et al. 2004). Without proper nutrient transfer, which is largely dependent on blood flow, fetal growth and proper development can be significantly reduced. Studies using a growth restricted model (ewes restricted $40 \%$ compared to controls) have constantly shown that when pregnant ewe lambs are nutrient restricted during various periods of gestation, lamb birth weight is reduced (Meyer et al. 2010; Swanson et al. 2008), umbilical artery blood flow during mid-gestation is reduced (Lemley et al. 2012), and umbilical vascular resistance is increased (Vonnahme 2012). On the other hand, studies conducted by Wallace et al. $(1996,1997)$ have shown that over nourishing adolescent ewes throughout gestation led to a decrease in placental mass and a significant reduction in lamb birth weight at parturition. Over nourishment during gestation in the adolescent ewe favors maternal growth instead of partitioning nutrients to support the growth of the gravid uterus leading to inadequate growth of the fetus (Wallace et al. 2009). A similar study conducted by Wallace et al. (2003) found that overfeeding mature ewes throughout gestation had no effect on fetal growth. In summary, these data indicate that proper nutrient intake during gestation is essential for the proper growth and development of the fetus. Intrauterine growth restriction (IUGR) is not limited to feed intake but can also be caused by environmental conditions such as elevated temperatures leading to heat stress (Vonnahme 2012). A study conducted by Regnault et al. (2003) induced IUGR by placing pregnant ewes in hyperthermic conditions beginning on day 39 of gestation and ending near term. They found that ewes exposed to hyperthermic conditions throughout gestation had placentas which were approximately 50\% smaller than those from control ewes. A decrease in placental size is not seen 
mid to late term in nutrient restricted ewes during gestation, on the contrary, placental size in nutrient restricted ewes increases and may be due to the need to scavenge more nutrients from the blood (Vonnahme 2012).

Nutrients are delivered to various tissues throughout the maternal body based on the metabolic rate of those tissues (Hammond 1944; Barcroft 1946). When nutrients are limited, tissues with a lower metabolic rate have less priority to receive nutrients than do tissues with higher metabolic activities (Redmer et al. 2004). Tissues with high metabolic activity have greater nutrient delivery due to increased blood flow to those tissues, thus blood flow is the limiting factor of nutrient delivery to specific tissues (Redmer et al. 2004). During gestation the gravid uterus receives a large portion of cardiac output to support the growing conceptus, however, during compromised pregnancies blood flow to the gravid uterus is reduced in order to support the needs of the dam (Barker et al. 1997; Redmer et al. 2004; Reynolds et al. 2005). When nutrient intake is restricted, the rate of cell division is significantly reduced which is either due to the effect of undernutrition or the altered concentration of growth factors such as insulin like growth factors and/or growth hormone (Barker et al. 1997). The decrease in specific factors required for the proper growth and development may lead to the improper growth of the developing fetus. 


\title{
THE EFFECT OF MELATONIN OR MATERNAL NUTRIENT
}

\section{RESTRICTION ON CELL PROLIFERATION IN THE OVINE PLACENTA}

\author{
A. W. Eifert ${ }^{1, *}$, M. E. Wilson ${ }^{1}$, K. A. Vonnahme ${ }^{2}$, P. P. Borowicz ${ }^{2,3}$, D. A. Redmer ${ }^{2,3}$, S. \\ Dorsam $^{2}$, J. Haring ${ }^{2}$, C. O. Lemley ${ }^{4}$ \\ ${ }^{1}$ Animal and Nutritional Sciences, West Virginia Univ., Morgantown, ${ }^{2}$ Animal Science, \\ ${ }^{3}$ Advanced Imaging and Microscopy Core Lab, North Dakota State Univ., Fargo, ${ }^{4}$ Animal and \\ Dairy Sciences, Mississippi State Univ., Mississippi State, United States
}

Division of Animal and Nutritional Sciences, Davis College of Agriculture, Natural Resources, and Design, West Virginia University Morgantown, West Virginia, USA

Address all correspondence and requests for reprints to: Matthew E. Wilson, Ph.D., Division of Animal and Nutritional Sciences, Davis College of Agriculture, Natural Resources and Design, West Virginia University, P. O. Box 6108, Room GO48, Morgantown, West Virginia 26506. E-mail: Matt.Wilson@mail.wvu.edu

This work is published with the approval of the Director of West Virginia Agriculture and Forestry Experiment Station as scientific paper.

Keywords: Fetal Development, Gestational Nutrition, Melatonin 


\section{Introduction}

Melatonin is a neurohormone produced from the amino acid tryptophan and secreted from the pineal gland on a diurnal rhythm depending on environmental lighting conditions. Melatonin has been found to regulate seasonal reproduction in a variety of animals including the ewe (Monroe et al. 1998; Yellon and Longo 1987). Additionally, melatonin is unique in that it is one of the few maternal hormones that is able to cross the placenta unaltered (Torres-Farfan et al. 2008). Previous studies have shown that melatonin supplementation has been associated with decreasing uterine contractility in the rat, stimulating the secretion of progesterone (Forcada et al. 2006), increasing the release of gonadotropins from the pituitary in the ewe (Aleandri et al. 2006), and removal of the pineal gland in pregnant rats has been linked to an elevated incidence of spontaneous abortions (Sandyk et al. 1992).

Adequate maternal nutrition during gestation is essential for the proper growth and survival of the developing conceptus. During gestation in mammals, the placenta is the organ which is responsible for the transfer of nutrients, oxygen, and immunological factors such as cytokines and lymphocytes from the mother to the fetus. Studies have shown that when pregnant ewe lambs are nutrient restricted during various periods of gestation, lamb birth weight is reduced (Meyer et al. 2010; Swanson et al. 2008), umbilical artery blood flow during mid gestation is reduced (Lemley et al. 2012), and umbilical vascular resistance is increased (Vonnahme 2012). These data indicate that proper nutrient intake during gestation is essential for the proper growth and development of the fetus.

Lemley et al. $(2012,2013)$ found that supplementing ewes with melatonin either through the feed or direct infusion into the mesometrial region of the gravid uterus during mid gestation decreased caruncle weight (2013), increased fetal abdominal girth (2012), and increased 
umbilical blood flow (2013). These results led us to hypothesize that supplementation with melatonin during mid gestation would offset the negative effects of nutrient restriction during mid gestation and increase placental cell proliferation. The hypothesis was tested through two separate studies. First, we wanted to determine the effects of chronic in vivo infusions of vehicle, melatonin or melatonin antagonist on placental cell proliferation during mid-gestation. Secondly, we wanted to determine if supplementing melatonin directly into the feed would increase placental cell proliferation in ewes that were nutrient restricted during mid gestation.

\section{Materials and Methods}

All protocols involving animals were approved by the North Dakota State University Intuitional Animal Care and Use Committee protocol \#A11061 (infusion study) and protocol \#A10071 (dietary study).

\section{Animal management for Infusion Study}

The animal management, breeding, and experimental design were previously published (Lemley et al., 2013). Initially, 24 primiparous ewes were placed on pasture with ad libitum access to hay and water with one ram of proven fertility fitted with a crayon marking harness. Mating was recorded every 12 hours. At day 28 after breeding, ewes were transported to the Animal Nutrition and Physiology Center (ANPC; Fargo, ND) which is a temperature controlled facility $\left(14^{\circ} \mathrm{C}\right)$ with a 12:12 light: dark cycle with lights on at 07:00 hours and off at 19:00 hours for the remainder of the study. The study was conducted in August of 2011 and ewes were fed to meet early gestational nutrient requirements beginning on day 28 of gestation. Ewes carrying singleton pregnancies were assigned to treatments and housed in individual pens $(0.91 \times 1.2 \mathrm{~m})$ 
at ANPC for the remainder of the experiment. On day 35 of gestation ewes were acclimated to a common alfalfa hay diet ( $2 \%$ of body weight), provided trace mineralized salt blocks (American Stockman, Overland Park, KS), and ad libitum access to water.

\section{Surgeries for Infusion Study}

Melatonin was purchased from Spectrum Chemical Mfg. Corp. (Gardena, CA) and luzindole was purchased from Santa Cruz Biotechnology, Inc. (Santa Cruz, CA). One day prior to surgery (day 61 of gestation) Alzet mini-osmotic pumps (model 2ML4; Durect Corporation, Cupertino, CA) were prepared using aseptic techniques. The 2ML4 model has a mean pumping rate of $2.80 \mu \mathrm{L} / \mathrm{hr}$ (standard deviation of $0.14 \mu \mathrm{L} / \mathrm{hr}$ ), a mean fill volume of $2100 \mu \mathrm{L}$, and a pumping duration of 28 days (without catheter attachments). Melatonin and luzindole were prepared at a concentration of $1 \mathrm{mg} / \mathrm{mL}$ in vehicle and then sterile filtered. In addition, vehicle alone (45\% DMSO in water) was sterile filtered for control ewes. Melatonin, luzindole, or vehicle were loaded into mini-osmotic pumps and then attached to a $20 \mathrm{~cm}$ PE-60 polyethylene catheter preloaded with the respective infusion treatment. The mini-osmotic pump and catheter attachment were completely submerged in sterile filtered saline and kept at $37^{\circ} \mathrm{C}$ overnight (one day prior to surgery).

On day 62 of gestation, ewes were weighed and anesthetized with sodium pentobarbital at $3 \mathrm{mg} / \mathrm{kg}$ sodium pentobarbital per $20 \mathrm{~kg}$ of body weight. Anesthesia was maintained via a jugular catheter. The abdomen was sheared and cleaned with betadine scrub. Through a mid-line abdominal incision the gravid uterine horn was exposed. During surgery the uterus was covered with warm surgical towels, and liberal amounts of sterile saline $\left(37^{\circ} \mathrm{C}\right)$ were applied to the uterus every 5 minutes. Pumps and catheters were sutured under the perimetrium and catheters were 
advanced to the gravid uterine vascular network (arterial and venous) of the mesometrial region. Post-surgical care consisted of twice daily i.m. injections of flunixin meglumine $(50 \mathrm{mg} / \mathrm{mL}$; Prevail; Meridian, ID) and once daily i.m. injections of Penicillin G Procain (300,000 U/mL; Durvet; Blue Springs, MO) for the first 2 days post-surgery, following manufacturer recommendations. In addition, ewes were provided 50\% of their rations post-surgery and feed was increased in a stepwise manner during this post-operative phase. Fifteen ewes were selected for this surgical procedure and all fetuses were viable during the 4 week infusion period; however, one ewe was removed because of a twin pregnancy.

\section{Tissue Collection for Infusion Study}

On day 90 of gestation (following the 4 week chronic uterine infusion) ewes were euthanized via captive bolt followed by exsanguination. The uterus was removed at the cervix and the fetus was dissected from the gravid uterine horn. Fetal membranes were removed and several placentomes were dissected from the uterine wall, weighed, and flash frozen for later analysis. Caruncular and cotyledonary tissues were separated, weighed, flash frozen, and stored at $-80^{\circ} \mathrm{C}$ for further analysis.

\section{Animals and Treatments for Dietary Study}

The animal management, breeding, and experimental design were previously published (Lemley et al. 2012). Nulliparous Western white face ewe lambs ( $n=64)$ and 2 rams fitted with crayon marking harnesses were put on pasture with ad libitum access to hay and water. Mating was recorded daily at twelve hour intervals. On d 28 of gestation, dams were transported to the Animal Nutrition and Physiology Center (ANPC; Fargo; ND) which is a ventilated, temperature 
controlled facility $\left(14^{\circ} \mathrm{C}\right)$ with 12:12 h light-dark cycle with lights on at 07:00 and off at 19:00. The study was conducted in September of 2010 and ewes were fed to meet their early gestational nutrition requirements beginning on d 28 of gestation. At ANPC, pregnancy was determined during days 28 through 35 using a B mode ultrasound (model SSD-3500; Aloka America, Wallingford, CT) fitted with a 7.5 MHz, linear transrectal probe, adapted from Schrick and Inskeep (1993; Lemley et al. 2012). Lutalyse was administered to ewes carrying multiple conceptuses and reintroduced to the rams 2 wk later. Ewes carrying singletons were individually housed in $0.91 \times 1.2 \mathrm{~m}$ pens at ANPC for the duration of the study.

Previous work conducted at NDSU on mid- to late-gestational maternal under nutrition has shown to be an effective model to observe the effects of under nutrition during this stage of pregnancy. This IUGR model has consistently resulted in decreased fetal weight, decreased birth weight, no difference in placental weight, and decreased postnatal growth rates (Meyer et al., 2010; Lemley et al., 2012).

\section{Nutritional Supplementation for Dietary Study}

On d 50 of gestation, ewes were assigned to one of four treatment groups consisting of 5 mg of melatonin (MEL; Spectrum Chemical Mfg., Gardena, CA) or no melatonin (CON) and supplied 100\% (adequate diet; ADQ) or 60\% (restricted; RES) of NRC recommendations (1985) for the remainder of the study. The four resulting treatment groups consisted of CON-ADQ $(\mathrm{n}=7), \operatorname{MEL}-\mathrm{ADQ}(\mathrm{n}=8)$, CON-RES $(\mathrm{n}=8)$, MEL-RES $(\mathrm{n}=8)$. Nutrient recommendations were set based on the mid- to late- gestational requirements for a $60 \mathrm{~kg}$ body weight pregnant ewe lamb. All ewes were fed and/or supplemented five hours before the start of the dark cycle at 1400 with melatonin enriched pellets. A melatonin solution was made by dissolving powered 
melatonin in $95 \%$ ethanol at a concentration of $5 \mathrm{mg} / \mathrm{ml}$. A day prior to feeding, $1 \mathrm{ml}$ of the melatonin solution was applied to control pellets $(100 \mathrm{~g})$ and placed in a plastic bag to allow the ethanol to evaporate overnight at room temperature with no exposure to light (Lemley 2012). At 1400 , the melatonin supplemented pellets $(100 \mathrm{~g})$ were fed to the MEL groups and were consumed within $\sim 5$ minutes. After the consumption of the melatonin treated pellets, the remainder of the control pellet was divided between all melatonin treated animals.

\section{Tissue Collection for Dietary Study}

On day 130 of gestation, ewes were weighed and anesthetized with sodium pentobarbital at $3 \mathrm{mg} / \mathrm{kg}$ of body at 08:00. A catheter was inserted into the jugular vein and used to maintain anesthesia via intermittent infusion with sodium pentobarbital. The following surgical procedures were non-survival; however aseptic techniques were used to preserve tissue samples for later analysis. The abdomen was sheared and cleaned with Betadine and the uterus was exposed via a midventral laparotomy, covered with warm surgical towels and liberal amounts of saline $\left(37^{\circ} \mathrm{C}\right)$ were applied to the uterus every 5 minutes. Intraoperative uterine and umbilical blood flows were determined using duplex B-mode and D-mode program of the color Doppler ultrasound instrument (Lemley et al., 2012). Prior to ewe euthanasia the gravid uterine horn was dissected and the fetus was removed under general anesthesia before the uterus was removed at the cervix. Fetal membranes were removed and several placentomes were dissected from the uterine wall, weighed, and flash frozen for later analysis. Caruncular and cotyledonary tissues were separated, weighed, flash frozen, and stored at $-80^{\circ} \mathrm{C}$ for further analysis.

\section{Measurement of Placentome Cellular Proliferation}


Placentomes excised from pregnant ewes on days 90 (infusion study; Experiment 1) and 130 (feeding study; Experiment 2) of gestation were analyzed using an immunofluorescence protocol developed at NDSU specific for cell proliferation. Fresh placentomes were fixed in a $10 \%$ solution of neutral buffered formalin containing $4 \%$ formaldehyde for $<24$ hours and transferred to a $70 \%$ ethanol solution. After fixation, the placentomes were embedded in paraffin and $5 \mu \mathrm{m}$ tissue sections were made and mounted on glass slides to prepare for staining. The prepared tissue samples from all ewes were incubated with a KI-67 mouse monoclonal antibody (VP-k452 Vector Laboratories) at 1:350 (6 $\mu \mathrm{L} / 2.1 \mathrm{~mL}$ of blocking buffer). To label the primary antibody, a goat anti-mouse IgG secondary antibody conjugated to Alexa-647 fluorophore (A21235, Life Technologies) was applied to the slides for a 1 hour incubation period. In order to differentiate between the maternal and fetal sides of the placentome, rhodamine labeled lectin (RL-1102, Vector Laboratories) was applied to the slides following the secondary antibody incubation. Before applying the cover slips, a drop of Prolong Gold anti-fade reagent with DAPI (P36931, Life Technologies) was added to each slide as a nuclear counter stain. Cellular proliferation was quantified using Image-Pro Plus (Media-Cybernetics Inc.).

\section{Image Analysis}

Photomicrographs were taken at 20x magnification in a low light environment using a Zeiss Axio Imager 2 microscope (Zeiss, Oberkochen, Germany). Because KI-67, rhodamine lectin and DAPI fluoresce at different wave lengths $(625 \mathrm{~nm}, 555 \mathrm{~nm}$, and $365 \mathrm{~nm}$ respectively), a picture was taken at each specific wave length. The three pictures were then overlaid to get a representative image of the sample. This was repeated at four other random sections of the slide for each sample. The resulting images were analyzed using Image-Pro Plus software (Media- 
Cybernetics Inc). For each image, the fetal and maternal portions were distinguished and a macro was developed to quantify the total area of maternal or fetal tissue as well as the area of proliferating and non-proliferating cells. By obtaining the average area of a proliferating and non-proliferating cell, the quantity of each could be determined for each treatment group.

\section{Cellularity Estimates (DNA, RNA, and Protein)}

Individually frozen caruncular and cotyledonary tissues were ground into a fine powder using a mortar and pestle while submerged in liquid nitrogen and transferred to a chilled tube to allow the excess liquid nitrogen to evaporate. AllPrep DNA/RNA/Protein Mini kit (Qiagen, Hilden, Germany) was used to quantify the amount of DNA, RNA, and protein present in both cotyledonary and caruncular tissues from both the infusion and feeding studies. Supplied buffer (buffer RLT) was then added and the sample was homogenized using a Tissuemiser (Fisher Scientific, Waltham, MA). The lysate was centrifuged at full speed (18,000 RCF) for three minutes before being transferred to a DNA spin column. DNA and RNA were extracted and washed according to Qiagen's protocol and were eluted to a final volume of $50 \mu \mathrm{L}$ of RNase free water (RNA), or $100 \mu \mathrm{L}$ of Buffer EB (DNA) before being quantified using NanoDrop spectrophotometer (ND-1000, Thermo Scientific, Waltham, MA).

Tissue homogenates suspended in buffer (buffer RLT, Qiagen) were used to assess total protein. The prepared tissue homogenates were quantified with Coomassie Brilliant blue $\mathrm{G}$ (Bradford, 1976) using bovine serum albumin (Thermo Scientific, Waltham, MA) as the standard. The prepared samples were measured at $595 \mathrm{~nm}$ using a spectrophotometer (Spectra Max Plus 384, Molecular Devices, Sunnyvale, CA). The concentration of DNA was used as an 
index of cell number with protein:DNA ratio a measure of cell size, and RNA:DNA ratio used as an index of transcriptional activity (Reed 2007).

\section{Statistics}

Data for the melatonin infusion were analyzed using the MIXED procedure of SAS (SAS Software version 9.2, SAS Institute Inc., Cary, NC). Fetal sex was included in the model, and it was removed if $\mathrm{P} \geq 0.25$. The model compared means across all three treatments; control (con), melatonin (mel), or luzindole (luz). Data were considered significant if the $\mathrm{P}<0.10$.

Data for the melatonin feeding study were analyzed as a completely randomized $2 \mathrm{x} 2$ factorial design using the MIXED procedure of SAS (SAS Software version 9.2, SAS Institute Inc., Cary, NC). Fetal sex and breeding date were included in the model to help control for variation in the number of male vs. female fetuses or the date of breeding. If fetal sex and breeding date had a $\mathrm{P} \geq 0.25$, they were removed from the model statement. The model contained the effects for nutritional plane (adequate and restricted), melatonin supplementation (control versus melatonin), and the interaction between nutritional plane and melatonin supplementation. In the absence of interactions, main effects were considered significant when $\mathrm{P}$ $<0.05$.

\section{Results}

\section{Study 1 (Infusion Study)}

\section{Gross weights and blood flow}

Maternal body weight, placental size, fetal size, and umbilical blood flow at day 90 of gestation are illustrated in Table 1. These data were adapted from Lemley et al. (2013). Ewe final 
body weight, gravid uterine weight, and empty uterine weight at day 90 of gestation were not different $(\mathrm{P}>0.30)$ across all treatment groups. Placentome weight and cotyledon weight were not different $(\mathrm{P}>0.08)$ across all treatment groups at day 90 of gestation; however, caruncle weight was decreased $(\mathrm{P}<0.05)$ in both LUZ and MEL infused dams versus CON infused. Fetal weight, crown rump length, and ponderal index at day 90 of gestation were not different (P > $0.10)$ across all treatments. In contrast fetal abdominal girth was increased $(\mathrm{P}<0.05)$ in melatonin versus luzindole infused dams with vehicle control infused dams being intermediate (Table 1).

\section{Cellularity estimates}

Placental cellularity estimates are illustrated in Table 2. In caruncular tissue, treatment did not affect $(\mathrm{P} \geq 0.15)$ the concentration of DNA, RNA or protein. There was no effect $(\mathrm{P} \geq$ 0.21) of treatment on the ratio of DNA:RNA, and the ratio of protein:DNA. In cotyledonary tissue, there was no effect $(\mathrm{P} \geq 0.17)$ of melatonin, luzindole or vehicle infusion treatment on DNA, RNA, or protein concentrations. The DNA:RNA ratio as well as the protein:DNA ratio was also not affected by treatment $(\mathrm{P} \geq 0.60)$.

\section{Placentome cellular proliferation}

Placentome cellular proliferation is illustrated in Table 2. Treatment of ewes with 1 $\mathrm{mg} / \mathrm{mL}$ of melatonin, luzindole, or vehicle delivered at a rate of $2.80 \mu \mathrm{L} / \mathrm{hr}$ for 28 days did not affect $(\mathrm{P} \geq 0.30)$ the percentage of KI-67 positive cells in either caruncular or cotyledonary tissue. There was also no effect $(\mathrm{P} \geq 0.39)$ of fetal sex on the percentage of KI-67 positive cells in either caruncular or cotyledonary tissue (data not shown). 
Table 1. Ewe body weight, placenta size, fetal size, and uteroplacental blood flow at day 90 of gestation from ewes chronically infused with luzindole (LUZ), vehicle control (CON), or melatonin (MEL) beginning on day 62 of gestation.

\begin{tabular}{lccccc}
\hline \hline & & & & \multicolumn{2}{c}{$P$-value } \\
\cline { 4 - 6 } Dependent variable & LUZ & CON & MEL & SE & Trt \\
\hline Ewe weight, kg & 69.2 & 64.2 & 67.8 & 5.9 & 0.82 \\
Gravid uterine weight, kg & 2.6 & 2.4 & 2.6 & 0.2 & 0.74 \\
Empty uterine weight, g & 359 & 364 & 388 & 16 & 0.36 \\
Placenta & & & & & \\
Placentome weight, g & 590 & 551 & 490 & 43 & 0.21 \\
Caruncle weight, g & $102^{\mathrm{b}}$ & $159^{\mathrm{a}}$ & $97^{\mathrm{b}}$ & 13 & 0.01 \\
Cotyledon weight, g & 432 & 363 & 329 & 35 & 0.09 \\
Fetal weight, g & 572 & 567 & 612 & 43 & 0.67 \\
Crown rump length $(\mathrm{cm})$ & 26 & 27 & 27 & 1 & 0.33 \\
Ponderal index $\left(\mathrm{kg} / \mathrm{m}^{3}\right)$ & 32 & 29 & 29 & 1 & 0.15 \\
Abdominal girth $(\mathrm{cm})$ & $16.7^{\mathrm{b}}$ & $17.5^{\mathrm{ab}}$ & $18.2^{\mathrm{a}}$ & 0.4 & 0.01 \\
Umbilical artery, $\mathrm{ml} / \mathrm{min}$ & $130^{\mathrm{b}}$ & $141^{\mathrm{b}}$ & $200^{\mathrm{a}}$ & 17 & 0.02 \\
\hline
\end{tabular}

a,b Least square means with different letter superscripts depict differences $P<0.05$.

*Data adapted from Lemley et al. (2013). 
Table 2. Placenta measures of DNA, RNA, protein and cellular proliferation at day 90 of gestation from ewes chronically infused with luzindole (LUZ), vehicle control (CON), or melatonin (MEL) beginning on day 62 of gestation.

\begin{tabular}{lccccc}
\hline \hline & & & & & $P$-value \\
\cline { 5 - 6 } Dependent variable & LUZ & CON & MEL & SE & Trt \\
\hline Caruncle & & & & & \\
DNA, mg/g & 4.3 & 3.7 & 4.6 & 0.6 & 0.48 \\
RNA, mg/g & 5.4 & 5.5 & 5.2 & 0.9 & 0.97 \\
Protein, mg/g & 124 & 128 & 131 & 3 & 0.15 \\
RNA:DNA & 1.5 & 1.8 & 1.2 & 0.4 & 0.31 \\
Protein:DNA & 32 & 47 & 33 & 8 & 0.21 \\
Proliferating cells, \% & 1.2 & 1.9 & 1.5 & 0.2 & 0.39 \\
Cotyledon & & & & & \\
DNA, mg/g & 4.1 & 3.0 & 4.3 & 1.3 & 0.66 \\
RNA, mg/g & 8.2 & 5.1 & 7.0 & 1.4 & 0.17 \\
Protein, mg/g & 143 & 139 & 144 & 4 & 0.44 \\
RNA:DNA & 2.4 & 1.7 & 1.8 & 0.7 & 0.60 \\
Protein:DNA & 42 & 48 & 42 & 11 & 0.84 \\
Proliferating cells, \% & 8.3 & 8.1 & 6.7 & 1.7 & 0.47 \\
\hline
\end{tabular}




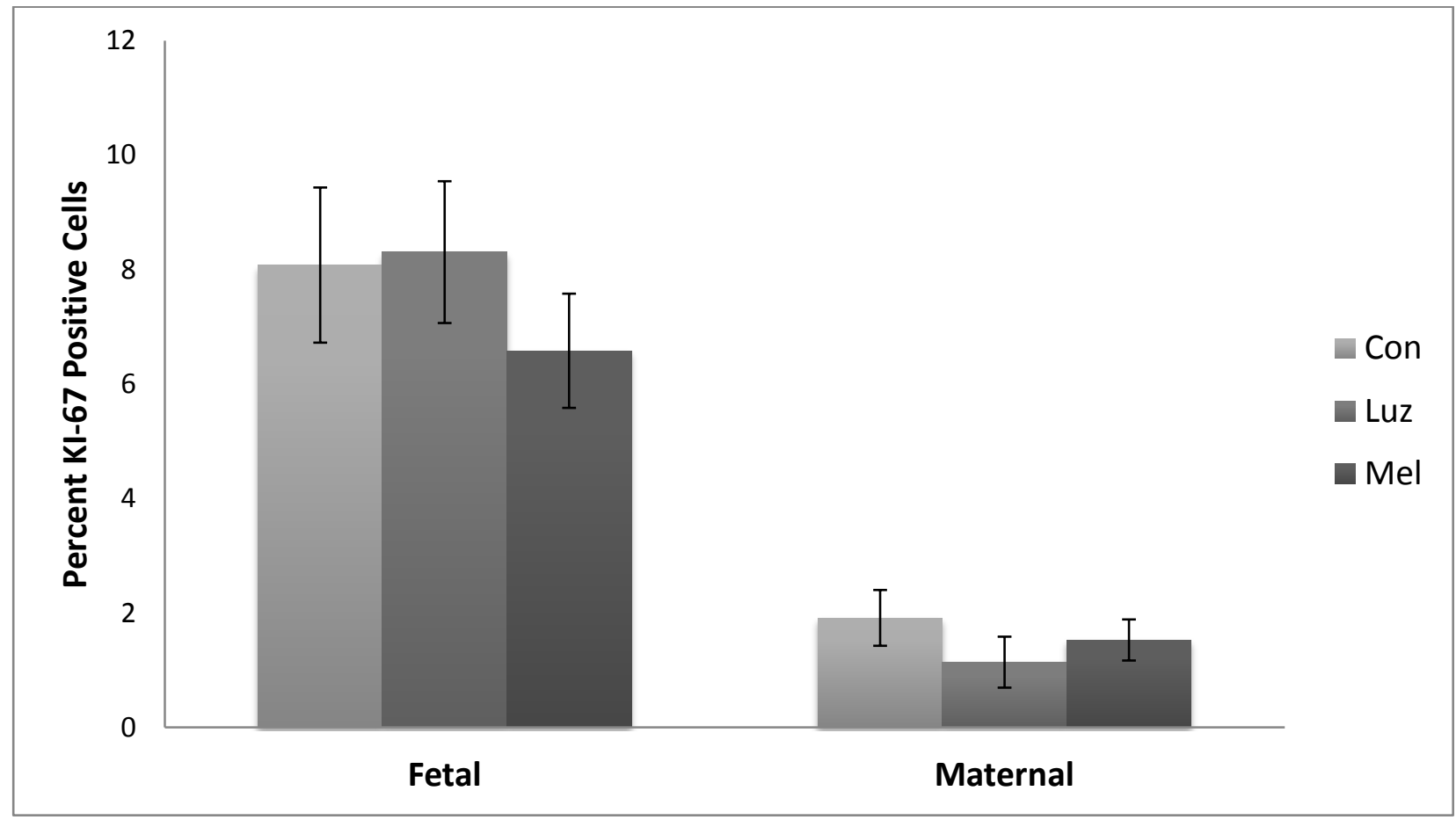

Figure 1. Cellular proliferation based on percent KI-67 positive cells at day 90 of gestation from ewes chronically infused with luzindole (LUZ), vehicle control (CON), or melatonin (MEL) beginning on day 62 of gestation. 


\section{Study 2 (Dietary Study)}

\section{Gross weights}

Maternal body condition, placental size, fetal size, and uteroplacental blood flow at day 130 of gestation are illustrated in Table 3. These data were adapted from Lemley et al. (2012). Ewe final body weight and empty uterus weight at day 130 of gestation were decreased in RES versus ADQ fed ewes. No main effects or interactions were observed for placentome weight or placentome number $(P>0.10)$. Fetal weight was decreased $(P<0.01)$ in RES versus ADQ fed ewes. At day 130 of gestation umbilical blood flow was increased $(P<0.05)$ by approximately $20 \%$ in MEL versus CON ewes, with no effect $(P>0.30)$ of nutritional plane on umbilical artery blood flow. In contrast, uterine artery blood flow was decreased $(P<0.05)$ by approximately $20 \%$ in RES versus ADQ fed ewes, with no effect $(P>0.25)$ of melatonin supplementation on uterine artery blood flow.

\section{Cellularity estimates}

Placental cellularity estimates are illustrated in Table 4 . There was no effect $(P \geq 0.21)$ of nutritional plane or melatonin treatment on DNA or protein concentrations in caruncular tissue. However, there was a significant $(\mathrm{P}=0.02)$ melatonin treatment $\mathrm{x}$ nutritional plane interaction for maternal RNA concentrations in caruncular tissue. Ewes treated with melatonin under a restricted diet had an increase in RNA concentration compared to adequately fed ewes treated with melatonin. Although there were no melatonin treatment $\mathrm{x}$ nutritional plane interactions on the ratio of RNA:DNA or the ratio of protein:DNA in caruncular tissue. In cotyledonary tissue, neither melatonin supplementation nor nutritional plane affected $(\mathrm{P} \geq 0.20)$ DNA, RNA, or 
Table 3. Ewe body weight, placenta size, fetal size, and uteroplacental blood flow at day 130 of gestation from ewes supplemented with $5 \mathrm{mg}$ of melatonin (MEL) or no melatonin (CON) and provided 100\% (ADQ; adequate diet) or $60 \%$ (RES; restricted diet) of nutrient recommendations beginning on day 50 of gestation.

\begin{tabular}{|c|c|c|c|c|c|c|c|c|}
\hline \multirow[b]{2}{*}{ Dependent variable } & \multirow[b]{2}{*}{$\begin{array}{l}\text { CON } \\
\text { ADQ }\end{array}$} & \multirow[b]{2}{*}{$\begin{array}{l}\text { CON } \\
\text { RES }\end{array}$} & \multirow[b]{2}{*}{$\begin{array}{l}\text { MEL } \\
\text { ADQ }\end{array}$} & \multirow[b]{2}{*}{$\begin{array}{l}\text { MEL } \\
\text { RES }\end{array}$} & \multirow[b]{2}{*}{ SE } & \multicolumn{3}{|c|}{$P$-values ${ }^{\dagger}$} \\
\hline & & & & & & Trt & Nut & Trt*Nut \\
\hline Ewe weight, kg & 53 & 41 & 51 & 41 & 1 & 0.56 & $<0.01$ & 0.64 \\
\hline Empty uterus weight, g & 653 & 557 & 674 & 530 & 24 & 0.88 & $<0.01$ & 0.32 \\
\hline Placentome weight, g & 478 & 436 & 488 & 448 & 30 & 0.70 & 0.17 & 0.97 \\
\hline Fetal weight, g & 3405 & 3173 & $3691^{a}$ & 3066 & 110 & 0.40 & $<0.01$ & 0.07 \\
\hline Crown rump length, $\mathrm{cm}$ & 53.6 & 51.7 & 52.5 & 51.7 & 0.9 & 0.52 & 0.15 & 0.52 \\
\hline Ponderal index ${ }^{3}, \mathrm{~kg} / \mathrm{m}^{3}$ & $22.2^{\mathrm{b}}$ & $22.9^{\mathrm{b}}$ & $25.9^{\mathrm{a}}$ & $22.4^{\mathrm{b}}$ & 1.1 & 0.11 & 0.19 & 0.04 \\
\hline Abdominal girth, cm & $32.5^{\mathrm{b}}$ & $32.1^{\mathrm{b}}$ & $34.1^{\mathrm{a}}$ & $31.7^{\mathrm{b}}$ & 0.4 & 0.09 & $<0.01$ & $<0.01$ \\
\hline Uterine artery, $\mathrm{ml} / \mathrm{min}$ & 1261 & 1023 & 1520 & 1094 & 165 & 0.30 & 0.04 & 0.55 \\
\hline Umbilical artery, $\mathrm{ml} / \mathrm{min}$ & 650 & 643 & 805 & 710 & 67 & 0.04 & 0.37 & 0.42 \\
\hline
\end{tabular}

${ }^{\mathrm{a}, \mathrm{b}}$ Least square means with different letter superscripts depict differences $P \leq 0.05$.

${ }^{\dagger}$ Main effect of melatonin supplementation (Trt), main effect of nutritional plane (Nut), or the interaction between melatonin supplementation $\times$ nutritional plane $(\mathrm{Trt} * \mathrm{Nut})$. Least square means and SEM for main effects are reported in the text.

"Data adapted from Lemley et al. (2012).

Ponderal index calculated as fetal weight $(\mathrm{kg}) /$ crown rump length $(\mathrm{m})^{3}$. 
Table 4. Placenta measures of DNA, RNA, protein and cellular proliferation at day 130 of gestation from ewes supplemented with $5 \mathrm{mg}$ of melatonin (MEL) or no melatonin (CON) and provided 100\% (ADQ; adequate diet) or $60 \%$ (RES; restricted diet) of nutrient recommendations beginning on day 50 of gestation.

\begin{tabular}{|c|c|c|c|c|c|c|c|c|}
\hline \multirow[b]{2}{*}{ Dependent variable } & \multirow[b]{2}{*}{$\begin{array}{l}\text { CON } \\
\text { ADQ }\end{array}$} & \multirow[b]{2}{*}{$\begin{array}{l}\text { CON } \\
\text { RES }\end{array}$} & \multirow[b]{2}{*}{$\begin{array}{l}\text { MEL } \\
\text { ADQ }\end{array}$} & \multirow[b]{2}{*}{$\begin{array}{l}\text { MEL } \\
\text { RES }\end{array}$} & \multirow[b]{2}{*}{ SE } & \multicolumn{3}{|c|}{$P$-values ${ }^{\dagger}$} \\
\hline & & & & & & Trt & Nut & Trt*Nut \\
\hline \multicolumn{9}{|l|}{ Caruncle } \\
\hline DNA, mg/g & 2.2 & 2.3 & 1.8 & 2.8 & 0.4 & 0.83 & 0.18 & 0.20 \\
\hline RNA, mg/g & $2.8^{\mathrm{ab}}$ & $1.8^{\mathrm{b}}$ & $2.0^{\mathrm{b}}$ & $4.5^{\mathrm{a}}$ & 0.8 & 0.20 & 0.31 & 0.02 \\
\hline Protein, mg/g & 137 & 134 & 133 & 129 & 3 & 0.14 & 0.20 & 0.95 \\
\hline RNA:DNA & 1.4 & 1.1 & 1.2 & 1.8 & 0.5 & 0.69 & 0.74 & 0.33 \\
\hline Protein:DNA & 85 & 73 & 78 & 63 & 13 & 0.48 & 0.28 & 0.91 \\
\hline Proliferating cells, $\%$ & 0.69 & 0.70 & 0.76 & 0.92 & 0.04 & 0.33 & 0.58 & 0.59 \\
\hline \multicolumn{9}{|l|}{ Cotyledon } \\
\hline DNA, mg/g & 5.2 & 4.6 & 4.9 & 5.2 & 0.9 & 0.88 & 0.83 & 0.50 \\
\hline $\mathrm{RNA}, \mathrm{mg} / \mathrm{g}$ & 6.3 & 7.6 & 7.1 & 6.7 & 0.7 & 0.92 & 0.51 & 0.20 \\
\hline Protein, mg/g & 124 & 122 & 124 & 122 & 3 & 0.91 & 0.47 & 0.85 \\
\hline RNA:DNA & 1.7 & 1.9 & 1.7 & 1.4 & 0.3 & 0.35 & 0.98 & 0.25 \\
\hline Protein:DNA & 36 & 33 & 31 & 29 & 8 & 0.54 & 0.76 & 0.92 \\
\hline Proliferating cells, $\%$ & 5.6 & 5.3 & 6.6 & 6.7 & 0.7 & 0.08 & 0.73 & 0.58 \\
\hline
\end{tabular}

a,b Least square means with different letter superscripts depict differences $P \leq 0.05$.

${ }^{\dagger}$ Main effect of melatonin supplementation (Trt), main effect of nutritional plane (Nut), or the interaction between melatonin supplementation $\times$ nutritional plane ( $\mathrm{Trt}^{*} \mathrm{Nut}$ ). Least square means and SEM for main effects are reported in the text. 
protein concentrations. There was no effect $(\mathrm{P} \geq 0.25)$ of nutritional plane or melatonin treatment on the RNA:DNA ratio or the ratio of protein:DNA in cotyledonary tissue.

\section{Placentome cellular proliferation}

Placentome cellular proliferation is illustrated in Table 4. There were no melatonin treatment $x$ nutritional interactions $(\mathrm{P} \geq 0.58)$ or main effects of nutritional plane $(\mathrm{P} \geq 0.58)$ on placentome cellular proliferation of the caruncle or cotyledon. There was a tendency $(\mathrm{P}=0.08)$ for melatonin supplemented ewes to have an increased percentage of KI-67 positive cells in cotyledon tissue, but this effect was not present $(\mathrm{P}>0.33)$ in caruncle tissue. 


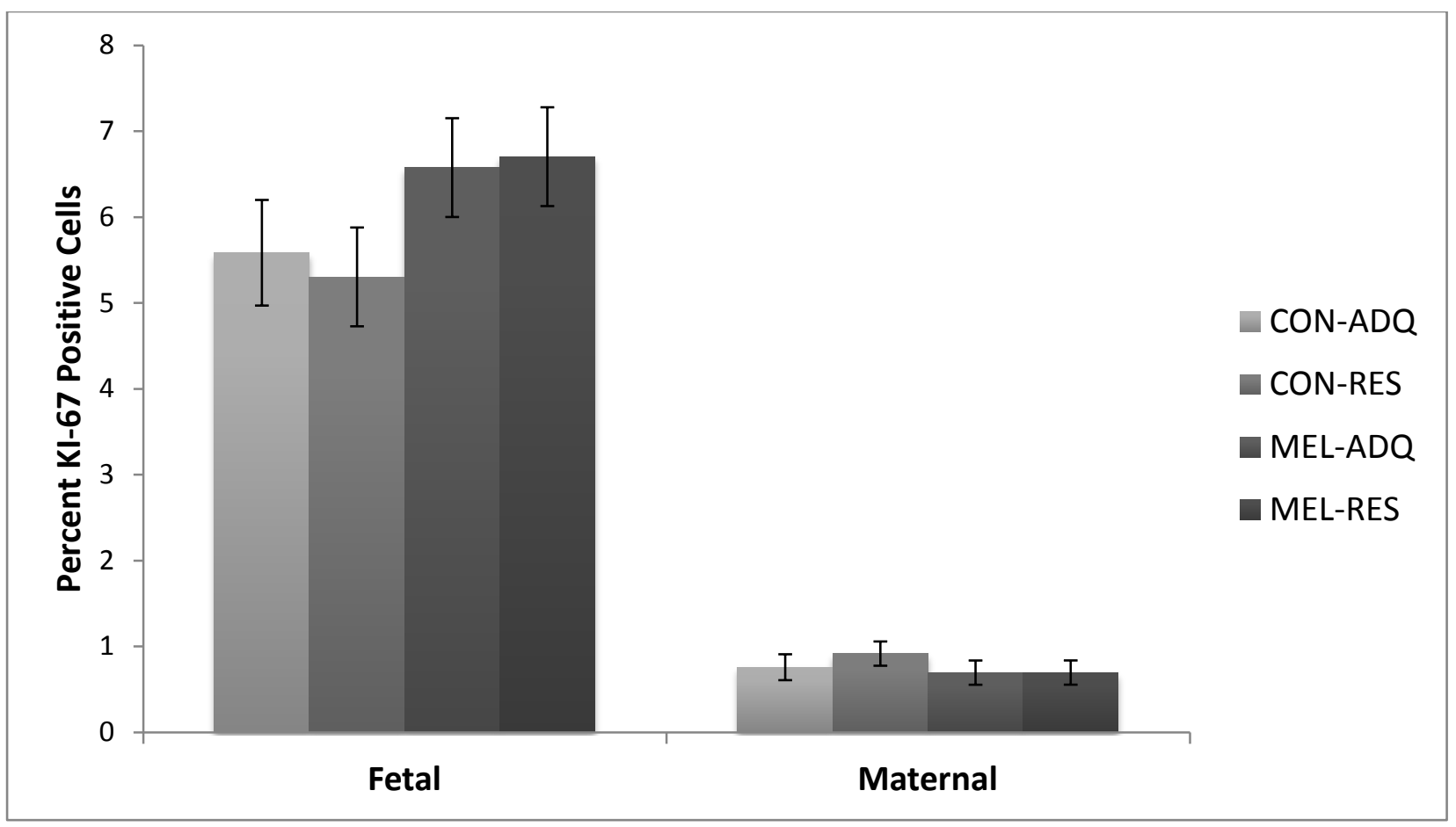

Figure 2. Cellular proliferation based on percent KI-67 positive cells at day 130 of gestation from ewes supplemented with $5 \mathrm{mg}$ of melatonin (MEL) or no melatonin (CON) and provided 100\% (ADQ; adequate diet) or 60\% (RES; restricted diet) of nutrient recommendations beginning on day 50 of gestation. 


\section{Discussion}

The present study indicates that chronic infusion with melatonin does not alter placental cellular proliferation when infused during mid-gestation. This observation does not suggest that melatonin does not play a role in increasing cellular proliferation during other stages of gestation. The majority of placental development occurs during the first two thirds of gestation (Redmer et al. 2004). Melatonin treatment may have varying levels of affect during early gestation when placental growth is just starting, although there have been no reports on the effect of melatonin infusion on cellular proliferation at this time point of pregnancy. Lemley et al. (2013) reported placentome weight and cotyledon weight were not different across all treatment groups at day 90 of gestation however, caruncle weight at day 90 of gestation was decreased in ewes infused with either luzindole or melatonin compared to controls. This indicates that placental growth may be altered by melatonin infusion during mid gestation. Sammin et al. (2009) found that placentomes reach their maximum size and mass by day 90 of gestation which explains why there was no difference in placentome weight between the three treatment groups at day 90 of gestation. However, the decrease in caruncle weight could be attributed to an increase in cellular turnover, although the exact mechanism by which this occurs remains unclear. Lemley et al. (2013) found that chronic infusion with melatonin, luzindole or vehicle for a 28 day period during mid-gestation did not alter ewe final body weight, gravid uterine weight, or empty uterine weight. Fetal growth parameters including fetal weight, crown rump length, and ponderal index were not different between the three treatment groups at day 90 of pregnancy (Lemley et al. 2013). However, fetal abdominal girth was increased in melatonin versus luzindole infused dams with vehicle infused dams being intermediate (Lemley et al. 2013). In our study, the same treatment did not alter the concentration of DNA, RNA or protein 
in any of the treatment groups as well as not altering the ratio of DNA:RNA or the ratio of protein:DNA in fetal or maternal tissues.

Dietary treatment with $5 \mathrm{mg}$ of melatonin per day for 80 days had a tendency to increase the percentage of proliferating cells in cotyledonary tissue although there was no effect in caruncular tissue. The precise mechanisms by which melatonin increases placentome cellular proliferation in cotyledonary tissue remains to be determined and needs to be further investigated. During the last third of gestation the rate of fetal development is greatly increased (Redmer et al. 2004). Additionally, placental and fetal nutrient requirements are highest during late pregnancy and in order for these nutrients to be delivered at a rate to keep pace with fetal growth, blood flow to the fetus must increase (Wallace et al. 2004). During late gestation in nutrient restricted pregnancies, uterine and umbilical blood flows are impaired (Reynolds et al. 2005). In the current work, Lemley et al. (2012) found that maternal melatonin supplementation during mid to late gestation increased umbilical blood flow by approximately $20 \%$ compared to control ewes. However, melatonin treatment did not alter uterine artery blood flow compared to controls (Lemley et al. 2012). There was also no affect of nutritional plane on placental cellular proliferation in either fetal or maternal tissues. Lemley et al. (2012) found that there was no change in placentome weight or number at day 130 of gestation due to placental development being complete at this period of pregnancy. RNA concentration was increased in the caruncular tissue of nutrient restricted ewes treated with melatonin although this was not seen in cotyledonary tissue. The increase in total RNA within the maternal portion of the placentome may be linked to an increase in gene expression and subsequently protein synthesis in caruncular tissue. Reactive oxygen species (ROS) especially $\mathrm{O}_{2}{ }^{\bullet-}$ react with nitric oxide (NO) to form peroxynitrite ( $\left.\mathrm{ONOO}^{-}\right)$which is a known oxidant and nitrating agent (Richter et al. 2009). This 
specific ROS has been shown to cause oxidative cellular damage and reduced blood flow due to the increase in sequestration of $\mathrm{NO}$ which is important in maintaining blood flow in placental and umbilical circulations (Schultz et al. 2004). A study conducted by Richter et al. (2009) found that nutrient restricted rats treated with melatonin had a significant increase in expression of the antioxidant enzymes Mn-SOD and catalase. This increase in antioxidant activity may decrease free radical production and ROS allowing for an increase in placental perfusion and the delivery of nutrients to the fetus in nutrient restricted pregnancies. However, there have been no studies looking at the affect of melatonin on the expression of antioxidant enzymes in the placenta of a nutrient restricted ewe. In our current study, the increased RNA concentration in caruncular tissue as well as the increase in umbilical blood flow reported by Lemley et al (2012) may be due to the antioxidant properties of melatonin. However, further research needs to be conducted regarding the role of melatonin on increasing the expression of antioxidant enzymes in an ovine model of IUGR.

To our knowledge there have been no reported studies on both the dietary treatment and infusion of melatonin and its effects on cellular proliferation during mid-gestation in an ovine model. However, there have been numerous studies on the effects of nutrient restriction on fetal growth and placental development during different times of pregnancy. Placental growth in terms of mass occurs during the first two thirds of gestation and maximal proliferative placental growth occurs between days 50 and 60 (Redmer et al. 2004; Heasman et al. 1998). The placenta is responsible for transporting nutrients to the fetus throughout gestation and without proper nutrient transfer, which is largely dependent on blood flow; fetal growth and development can be significantly reduced. Studies have shown that when ewes are nutrient restricted for periods of time throughout gestation, placental growth is reduced (McCrabb et al. 1991), birth weight is 
reduced (Meyer et al. 2010), amino acid concentration in both fetal and maternal blood plasma is reduced (Kwon et al. 2004), and placental angiogenesis is altered (Reynolds et al. 2005). Additionally, Clark et al. (1998) found that feeding ewes with half of the energy required to maintain pregnancy from day 30-80 of gestation, reduced mean placentome weight and total cotyledonary weight compared to animals fed to meet their nutrient requirements. In the present study, Lemley et al. (2012) found that nutrient restricted ewes had a decreased final body weight and empty uterine weight compared to adequately fed ewes with no main affect of melatonin supplementation. Moreover, fetal weight was reduced in nutrient restricted ewes compared with adequately fed ewes with no melatonin by nutritional plane interaction (Lemley et al. 2012). In conclusion, supplementing melatonin during mid-gestation either through the diet or infusion may help reduce the effects of IUGR, although this needs further investigation to better understand the mechanisms involved. Our results show that melatonin supplementation has a tendency to increase cotyledonary cell proliferation as well as increasing caruncular RNA expression and fetal umbilical blood flow. Methods that increase umbilical blood flow, cellular proliferation, and protein synthesis (as a result of increased RNA expression), may help rescue IUGR pregnancies. 


\section{References}

1. Abd-Allah RA, Sayed EM, Mohamed H, Abdel-Wahab Hamada FMA. Effect of melatonin on estrogen and progesterone receptors in relation to uterine contraction in rats. Pharmacol. Res. 47: 349-354, 2003.

2. Albecia JA, Forcada F, Casao A, Palacin I. Effect of exogenous melatonin on the ovary, the embryo and the establishment of pregnancy in sheep. Animal. 2(3): 399-404, 2008.

3. Albecia JA, Valares JA, Forcada F, Palacin I, Martin S, Martino A. The effect of melatonin on the reproductive performance of three sheep breeds in spain. Small Ruminant Res. 69: 1016, 2007.

4. Aleandri V, Spina V, Morini A. The pineal gland and reproduction. Human Reprod. 2(3): 225-235, 1996.

5. Almeida EA, Mascio PD, Harumi T, Spence WD, Moscovitch A, Hardland R, Cardinali DP, Brown GM, Pandi-Perumai SR. Measurement of melatonin in body fluids: standards, protocols and procedures. Childs Nerv. Syst. 27: 879-891, 2011.

6. Arendt J. Melatonin and the mammalian pineal gland. Chapman and Hall, London. 201-285, 1995.

7. Barker DJ, Clark PM. Fetal undernutrition and disease later in life. Rev. Reprod. 2: 105-112, 1997.

8. Benitez-King G, Anton-Tay F. Calmodulin mediates melatonin cytoskeletal effects. Experientia. 49(8): 635-641, 1993.

9. Bittman EL, Kaynard AH, Olster DH, Robinson JE, Yellon SM, Karsch FJ. Pineal melatonin mediates photoperiod control of pulsatile luteinizing hormone in the ewe. Neuroendocrinology. 40: 409-418, 1985. 
10. Bittman EL, Dempsey RJ, Karsch FJ. Pineal melatonin secretion drives the reproductive response to day length in the ewe. Endocrinology. 113: 2276-2283, 1983.

11. Bittman EL, Karsch FJ. Nightly duration of pineal melatonin secretion determines the reproductive response to inhibitory day length in the ewe. Biol. Reprod. 30: 585-593, 1984.

12. Bradford MM. A rapid and sensitive method for the quantification of microgram quantities of protein utilizing the principle of protein dye binding. Anal. Biochem. 72: 248-254, 1976.

13. Bronstein DM, Jacobs GH, Haak KA, Neitz J, Lytle LD. Action spectrum of the retinal mechanism mediating nocturnal light-induced suppression of rat pineal gland $\mathrm{N}-$ acetyltransferase. Brain Res. 406: 352-356, 1987.

14. Brydon L, Roka F, Petit L, de Coppet P, Tissot M, Barrett P, Morgan PJ, Nanoff C, Strosberg $A D$, Jockers R. Dual signaling of human Mel1a melatonin receptors via G(i2), G(i3), and G(q/11) proteins. Mol. Endo. 13(12): 2025-2038, 1999.

15. Bubenik GA. Thirty four years since the discovery of gastrointestinal melatonin. J. Physiol. Pharmacol. 58: 33-51, 2008.

16. Camacho LE, Meyer AM, Neville TL, Hammer CJ, Redmer DA, Reynolds LP, Caton JS, Vonnahme KA. Neonatal hormone changes and growth in lambs born to dams receiving differing nutritional intakes and selenium supplementation during gestation. Reproduction. 144: 23-35, 2012.

17. Chan AS, Lai FP, Lo RK, Voyno-Yasenetskaya TA, Stanbridge EJ, Wong YH. Melatonin MT1 and MT2 receptors stimulate c-Jun N-terminal kinase via pertusis toxin-sensitive and insensitive G-proteins. Cell. Singal. 14(3): 249-257, 2002.

18. Clark L, Heasman L, Juniper DT, Symonds ME. Maternal nutrition in early-mid gestation and placental size in sheep. Brit. J. Nutr. 77: 359-364, 1998. 
19. Claustrat B, Brun J, Chazot G. The basic physiology and pathophysiology of melatonin. Sleep Med. Rev. 9: 11-24, 2005.

20. Coon SL, Zarazaga LA, Malpaux B, Ravault JP, Bodin L, Voisin P, Weller JL, Kelin DL, Chemineau P. Genetic varability in plasma melatonin in sheep is due to pineal weight, not variations in enzyme activities. Am. J. Physiol. Endocrinol. 277: E792-E797, 1999.

21. Dardente H. Melatonin-Dependent Timing of Seasonal Reproduction by the Pars Tuberalis: Pivotal Roles for Long Daylengths and Thyroid Hormones. J. Neuroendo. 24: 249-266, 2011.

22. Deng WG, Tang ST, Tseng HP, Wu KK. Melatonin suppresses macrophage cyclooxygenase2 and inducible nitric oxide synthase expression by inhibiting p52 acetylation and binding. Blood. 108: 518-24, 2006.

23. Drew JE, Williams LM, Hannah LT, Barrett P, Abramovich DR. Melatonin receptors in the human fetal kidney: 2-[ $\left.{ }^{125}\right]$ idomelatonin binding sites correlated with expression of Mel 1a and Mel 1b receptor genes. J. Endocrinol 156: 261-267, 1998.

24. Dubocovich ML. Melatonin receptors: are there multiple subtypes? Trends Pharmacol. Sci. 16(2): 50-56, 1995.

25. Dubocovich ML, Masana MI, Iacob S, Sauri DM. Melatonin receptor antagonists that differentiate between the human Mel1a and Mel1b recombinant subtypes are used to assess the pharmacological profile of the rabbit retina ML1 presynaptic heteroreceptor. NaunynSchmiedebergs Archives of Pharmacology. 355(3): 365-375, 1997.

26. Dubocovich ML, Yun K, Al-Ghoul WM, Benloucif S, Masana MI. Selective M2 melatonin receptor antagonists block melatonin-mediated phase advances of circadian rhythms. FASEB Journal. 12(12): 1211-1220, 1998. 
27. Facciola G, Hidestrand M, Bahr CV, Tybring G. Cytochrome $\mathrm{P}_{450}$ isoforms involved in melatonin metabolism in human liver microsomes. Eur. J. Clin. Pharmacol. 56: 881-888, 2001.

28. Ferrazzi E, Rigano S, Padoan A, Bioto S, Pennati G, Galan HL. Uterine artery blood flow volume in pregnant women with an abnormal pulsatility index of the uterine arteries delivering normal or intrauterine growth restricted newborns. Placenta. 32: 487-492, 2011.

29. Finocchiaro LM, Glikin GC. Intracellular melatonin distribution in cultured cell lines. $J$. Pineal Res. 24(1): 22-24, 1998.

30. Forcada F, Abecia JA, Cebrian-Perez JA, Muino-Blanco T, Valares JA, Palacin I, Casao A. The effect of melatonin implants during the seasonal anestrus on embryo production after superovulation in aged high-prolificacy Rasa Aragonesa ewes. Theriogenology. 65: 356-365, 2006.

31. Forcada F, Zarazaga L, Abecia JA. Effect of exogenous melatonin and plane of nutrition after weaning on estrous activity, endocrine status and ovulation rate in Salz ewes lambing in the seasonal anestrus. Theriogenology. 43: 1179-1193, 1995.

32. Ford SP, Hess BW, Schwope MM, Jijland MJ, Gilbert JS, Vonnahme KA, Means WJ, Han H, Nathanielsz PW. Maternal undernutrition during early to mid-gestation in the ewe results in altered growth, adiposity, and glucose tolerance in male offspring. J. Anim. Sci. 85: 1285$1294,2007$.

33. Ganguly S, Coon SL, Klein DC. Control of melatonin synthesis in the mammalian pineal gland: the critical role of serotonin acetylation. Cell Tissue Res. 309: 127-137, 2002. 
34. Greenwood PL, Hunt AS, Hermanson JW, Bell AW. Effects of birth weight and postnatal nutrition on neonatal sheep: I. body growth and composition and some aspects of energetic efficiency. J. Anim. Sci. 76: 2354-2367. 1998.

35. Golombek DA, Pevet P, Cardinali DP. Melatonin effects on behavior: possible mediation by the central GABAergic system. Nurosci. Biobehav. Rev. 20: 403-412, 1996.

36. Hardeland R, Poeggeler B, Behrmann G, Fuhrberg B (1996) Enzymatic and non-enzymatic metabolism of methoxyindoles. In Metabolism and Cellular Dynamics of Indoles (Hardeland R, ed.), pp. 6-22. University of Goettingen, Goettingen.

37. Hardeland R, Reiter RJ, Poeggeler B, Tan DX. The significance of the metabolism of the neurohormone melatonin: antioxidative protection and formation of bioactive substances. Neurosci Biobehav. Rev. 17: 347-357, 1993.

38. Heasman L, Clarke L, Firth K, Stephenson T, Symonds ME. Influence of restricted maternal nutrition in early-mid gestation on placental and fetal development at term in sheep. Pediatr. Res. 44: 546-551, 1998.

39. Hirata F, Hayaishi O, Tokuyama T, Seno S. In vitro and in vivo formation of two new metabolites of melatonin. J. Biol. Chem. 249: 1311-1313, 1974.

40. Illnerova H, Backstrom M, Saaf J, Wetterberg L, Vanbo M. Melatonin in rat pineal gland and serum: rapid parallel decline after light exposure at night. Neurosci. Lett. 9: 189-193, 1978.

41. Itoh Mt, Ishizuka B, Kuribayashi Y, Amemiya A, Sumi Y. Melatonin, its precursors, and synthesizing enzyme activities in the human ovary. Mol. Hum. Reprod. 6: 402-408, 1999.

42. Kalsbeek A, Bujis RM. Output pathways of the mammalian suprachiasmatic nucleus: coding circadian time by transmitter selection and specific targeting. Cell Tissue Res. 2002. 
43. Karsch FJ, Woodfill CJI, Malpaux B, Robinson JE, Wayne NL. Melatonin and mammalian photoperiodism: synchronization of annual reproductive cycles. In Klein DC, Moore RY, Reppert SM (eds). Suprachiasmatic nucleus: the mind's clock. Oxford University Press. New York, 217-232, 1991.

44. Kennaway DJ, Matthews CD, Seamark RF, Phillipou G, Schilthuis M. On the presence of melatonin in pineal glands and plasma of foetal sheep. J. Steroid Biochem. 8: 559-563, 1977.

45. Klein DC. Photoneural regulation of the mammalian pineal gland. In: Evered D, Clark S (eds) Photoperiodism, melatonin, and the pineal. Ciba Foundation Symposium, Vol 117. Pittman Press, London. 38-56, 1985.

46. Klein DC, Lines SV. Pineal hydroxyindole-O-methyltransferase activity in the growing rat. Endocrinology. 84: 1523-1525, 1969.

47. Klein DC, Moore RY. Pineal N-acetyltransferase and hydroxyindole-O-methyltransferase: control by the retinohypothalamic tract and the suprachiasmatic nucleus. Brain Res. 174: 245-262, 1979.

48. Klein DC, Moore RY, Reppert SM. Suprachiasmatic nucleus: the minds clock. Oxford University Press, New York. 1991.

49. Klein DC, Weller JL. Rapid light-induced decrease in pineal serotonin N-acetyltransferase activity. Science. 177: 532-533, 1972.

50. Klein DC, Weller JL, Moore RY. Melatonin metabolism: Neural regulation of pineal serotonin: acetyl coenzyme A N-acetyltransferase activity. Proc. Nat. Acad. Sci. 68: 3107$3110,1971$. 
51. Kollmann MT, Locher M, Hirche F, Eder K, Meyer HHD, Bruckmaier RM. Effects of tryptophan supplementation on plasma tryptophan and related hormone levels in heifers and dairy cows. Domestic Animal Endocrinology. 34: 14-24, 2008.

52. Kwon H, Ford SP, Bazer FW, Spencer TE, Nathanielsz PW, Nijland MJ, Hess BW, Wu G. Maternal nutrient restriction reduces concentrations of amino acids and polyamines in ovine maternal and fetal plasma and fetal fluids. Biol. Reprod. 71: 901-908. 2004

53. Lekatz LA,Ward MA, Borrowicz PP, Taylor JB, Redmer DA, Grazul-Bilska AT, Reynolds LP, Caton JS, Vonnahme KA. Cotyledonary responses to maternal selenium and dietary restriction may influence alterations in fetal weight and fetal liver glycogen in sheep. $J$. Anim. Repro. Sci. 117: 216-225, 2009.

54. Lemley CO, Camacho LE, and Vonnahme KA. Uterine infusion of melatonin or melatonin receptor antagonist alters ovine feto-placental hemodynamics during mid-gestation. Biol. Reprod, (under review). 2013.

55. Lemley CO, Meyer AM, Camacho LE, Neville TL, Shukla P, O’Rourke ST, Caton JS, Vonnahme KA. Melatonin supplementation alters uteroplacental hemodynamics and fetal development in an ovine model of intrauterine growth restriction. Am. J. Physiol. Regul. Integr. Comp. Physiol. 302: R454-R467, 2012.

56. Liu C, Weaver DR, Jin X, Shearman LP, Pieschl RL, Gribkoff VK, Reppert SM. Molecular dissection of two distinct actions of melatonin on the suprachiasmatic circadian clock. Neuron. 19(1) 91-102, 1997.

57. Ma X, Idle JR, Krausz KW, Gonzalez FJ. Metabolism of melatonin by human cytochromes p450. Drug Metab. Dispos. 33: 489-494, 2005. 
58. McCrabb GJ, Egan AR, Hosking BJ. Maternal undernutrition during mid-pregnancy in sheep. Placental size and its relationship to calcium transfer during late pregnancy. Brit. J. Nutr. 65: 157-168, 1991.

59. Mendez-Pelaez A, Reiter RJ. Distribution of melatonin in mammalian tissues: the relative importance of nuclear versus cytosolic localization. J. Pineal Res. 15(2): 55-69, 1993.

60. Meyer AM, Reed JJ, Neville TL, Taylor JB, Hammer CJ, Reynolds LP, Redmer DA, Vonnahme KA, Caton JS. Effects of plane nutrition and selenium supply during gestation on ewe and neonatal offspring performance, body composition, and serum selenium. J. Anim. Sci. 88: 1786-1800, 2010.

61. Monroe K, Watts SW. The vascular reactivity of melatonin. Gen. Pharmacol. 30: 31-35, 1998.

62. Moore RY, Klein DC. Visual pathways and the central neural control of circadian rhythm in pineal serotonin N-acetyltransferase activity. Brain Res. 71: 17-33, 1974.

63. Mukasa-Mugerwa E, Said AN, Lahlou-Kassi A, Sherington J, Mutiga ER. Birth weight as a risk factor for perinatal lamb mortality, and the effects of stage pregnant ewe supplementation and gestation weight gain in Ethiopian Menz sheep. Prey. Vet. Med. 19: 45$56,1994$.

64. Nakamura Y, Tamura H, Kashida S, Takayama H, Yamagata Y, Karube A, Sugino N, Kato H. Changes of serum melatonin level and its relationship to feto-placental unit during pregnancy. J. Pineal Res. 30: 29-33, 2001

65. NASS, 2013.Sheep and Goats. Available: http://www.usda.gov/nass/PUBS/ TODAYRPT /sh ep0213.pdf. Accessed May 2, 2013. 
66. Nelson DE, Takahashi JS. Sensitivity and integration is a visual pathway for circadian entrainment in the hamster. J. Physiol. 439: 115-145, 1991.

67. Nosjean O, Ferro M, Coge F, Beauverger P, Henlin JM, Lefoulon F, Fauchere JL, Delagrange P, Canet E, Boutin JA. Identification of the melatonin binding site MT3 as the quinone reductases 2. J. Biol. Chem. 275(40): 31311-31317, 2000.

68. Nosjean O, Nicholas JP, Klupsch F, Delagrange P, Canet E, Boutin JA. Comparative pharmacological studies of melatonin receptors: MT1 MT2 and MT3/QR2, tissue distribution of MT3/QR2. Biochem. Pharmacol. 61(11): 1369-1379, 2001.

69. Pandi-Perumal SR, Sirnivasan V, Maestroni GJM, Cardinali DP, Poeggeler B, Hardeland R. Melatonin: Natures most versatile biological signal? FEBS J. 273: 2813-2838, 2006.

70. Pandi-Perumal SR, Trakhy I, Srinivasan V, Spence DW, Maestroni GJM, Zisapel N, Cardinali DP. The physiological effects of melatonin: role of melatonin receptors and signal transduction pathways. Prog. Neurobiol. 85: 335-353, 2008.

71. Paulis L, Simko F. Blood pressure modulation and cardiovascular protection by melatonin: potential mechanisms behind. Phyisol. Res. 56: 671-684, 2007.

72. Redmer DA, Wallace JM, Reynolds LP. Effect of nutrient intake during pregnancy on fetal and placental growth and vascular development. Domest. Anim. Endocrin. 27: 199-217, 2004.

73. Reed JJ, Ward MA, Vonnahme KA, Neville TL, Julius SL, Borowicz PP, Taylor JB, Redmer DA, Grazul-Bilska AT, Reynolds LP, Caton JS. Effects of selenium and dietary restriction on maternal and fetal body weight, visceral organ mass and cellulatiry estimates, and jejuna vascularity in pregnant ewe lambs. J. Anim. Sci. 85: 2721-2733, 2007. 
74. Regnault TR, de Vrijer B, Galan HL, Davidsen ML, Trembler KA, Battaglia FC, Wilkening RB, Anthony RV. The relationship between transplacental oxygen diffusion and placental expression of PIGF, VEGF, and their receptors in a placental insufficiency model of fetal growth restriction. J. Physiol. 550: 641-656, 2003.

75. Reiter RJ, Tan DX, Manchester LC, Paredes SD, Mayo JC, Sainz RM. Melatonin and reproduction revisited. Biol. Reprod. 81: 445-456, 2009.

76. Reppert SM. Maternal entrainment of the developing circadian system. Ann. NY Acad. Sci. 453: 162-169, 1985.

77. Reppert SM, Henshaw D, Schwartz WJ, Weaver DR. The circadian-gated timing of birth in rats: distribution by maternal SCN lesions or by the removal of the fetal brain. Brain Res. 403: 398, 1987.

78. Reppert SM, Perlow MJ, Ungerleider L, Mishkin M, Tamarkin L, Orloff DG, Hoffman H, Klein DC. Effects of damage to the suprachiasmatic area of the anterior hypothalamus on the daily melatonin and cortisol rhythms in the Rhesus monkey. J. Neurosci. 1: 1414-1425, 1981.

79. Reynolds LP, Borrowicz PP, Vonnahme KA, Johnson ML, Grazul-Bilska AT, Redmer DA, Caton JC. Placental angiogenesis in sheep models of compromised pregnancy. J Physiol. 556: 43-58, 2005.

80. Reynolds LP, Caton JS, Redmer DA, Grazul-Bilska AT, Vonnahme KA, Borowicz PP, Luther JS, Wallace JM, Wu G, Spencer TE. Evidence for altered placental blood flow and vascularity in compromised pregnancies. J. Physiol. 572: 51-58, 2006.

81. Richter HG, Hansell JA, Raut S, Giussani DA. Melatonin improves placental efficiency and birth weight and increases the placental expression of antioxidant enzymes in undernourished pregnancy. J. Pineal Res. 46: 357-364, 2009. 
82. Rosa HJD, Juniper DT, Bryant MJ. Effects of recent sexual experience and melatonin treatment of rams on plasma testosterone concentration, sexual behavior and ability to induce ovulation in seasonally anoestrous ewes. J. Reprod. Fertil. 120: 169-176, 2000.

83. Sammin D, Markey B, Bassett H, Buxton D. The ovine placenta and placentitis: a review. Vet. Microbiol. 135: 90-97, 2009.

84. Sampaio RV, Conceição SD, Miranda MS, Sampaio L, Ohashi OM. MT3 melatonin binding site, MT1 and MT2 melatonin receptors are present in oocyte, but only MT1 is present in bovine blastocyst produced in vitro. Repro Biol. Endo. 10:103, 2012.

85. Sandyk R, Anastasiadis PG, Anninos PA, Tsagas N. Is postmenopausal osteoporosis related to pineal gland functions? Int. J. Neurosi. 62(3-4): 215-225, 1992.

86. Schrick FN, Inskeep EK. Determination of early pregnancy in ewes utilizing transrectal ultrasonography. Theriogenology. 40: 295-306, 1993.

87. Schulz E, Anter E, Keaney JF Jr, Oxidative stress, antioxidants, and endothelial function. Curr. Med. Chem. 11: 1093-1104, 2004.

88. Semak I, Korik E, Antonova M, Wortsman J, Slominski A. Metabolism of melatonin by cytochrome $\mathrm{P}_{450}$ in rat liver mitochondria and microsomes. J. Pineal Res. 45: 515-523, 2008.

89. Senger PL. 2003. Pathways to Pregnancy and Parturition. $2^{\text {nd }}$ ed. Current Conceptions, Inc. Pullman WA.

90. Shelton M. Relation of birth weight to death losses and certain productive characters of fallborn lambs. J. Anim. Sci. 23: 355, 1964a.

91. Silva SO, Rodrigues MR, Kimenes VF, Bueno-de-Silva AEB, Amarante-Mendes GP, Campa A. Neutrophils as a specific target for melatonin and kynuramines: effect on cytokine release. J. Neuroimmunol. 156: 146-152, 2004. 
92. Slominski A, Tobin DJ, Zmijewski MA, Wortsman J, Paus R. Melatonin in the skin: synthesis, metabolism, and functions. Trends. Endocrin. Met. 19: 17-24, 2007.

93. Soares JM Jr, Masana MI, Ersahin C, Dubocovich ML. Functional melatonin receptors in rat ovaries at various stages of the estrous cycle. J. Pharmacol. Exp. Ther. 306: 694-702, 2006.

94. Sugden D, Klein DC. Activators of protein kinase C act as a post-receptor site to amplify cAMP production in rat pinealocytes. J. Neurochem. 32: 149-155, 1988.

95. Sugden D, Vanecek J, Klein DC, Thomas TP, Anderson WB. Activation of protein kinase C potentiates isoprenaline-induced cyclic AMP accumulation in rat pinealocytes. Nature. 314 : 359-361, 1985.

96. Sugden D, Yeh LK, Teh MT. Design of subtype selective melatonin receptor agonists and antagonists. Reprod. Nutr. Dev. 39(3): 335-344, 1999.

97. Swanson TJ, Hammer CJ, Luther JS, Carlson DB, Taylor JB, Redmer DA, Neville TL, Reynolds LP, Caton JS, Vonnahme KA. Effects of gestational plane of nutrition and selenium supplementation on mammary development and colostrums quality in pregnant ewe lambs. J. Anim. Sci. 86: 2415-2423, 2008.

98. Tan DX, Manchester LC, Reiter RJ, Plummer BF, Hardies LJ, Weintraub ST, Vijayalaxmi, Shepherd AM. A novel melatonin metabolite, cyclic 3-hydroxymelatonin: a biomarker of in vivo hydroxyl radical generation. Biochem. Biophys. Res. Commun. 253: 614-620, 1998.

99. Tamarkin L, Reppert SM, Orloff DJ, Klein DC, Yellon SM, Goldman BD. Otogeny of the pineal melatonin rhythm in the Syrian (Mesocricetus auratus) and Syberian (Phodopus sungorus) hamsters and in the rat. Endocrinology. 107: 1061-1064, 1980. 
100. Tamura H, Nakamura Y, Korkmaz A, Manchester LC, Tan DX, Sugino N, Reiter RJ. Melatonin and the ovary: physiological and pathophysiological implications. Fertil. Steril. 92(1): 328-343, 2009.

101. Tamura H, Takayama H, Nakamura Y, Reiter RJ, Sugino N. Fetal/placental regulation of maternal melatonin in rats. J. Pineal Res. 44: 335-340, 2008.

102. The NEI Connection. 2011. Marvelous melatonin. Available: http://neuroendoimmune.wordpress.com/2 011/08/18/marvelous-melatonin/. Accessed May $8,2013$.

103. Torres-Farfan C, Valenzuela FJ, Mondaca M, Valenzuela GJ, Krause B, Herreral EA, Riquelme R, Llanos AJ, Seron-Ferre M. Evidence of a role for melatonin in fetal sheep physiology: direct actions of melatonin on fetal cerebral artery, brown adipose tissue and adrenal gland. J. Physiol. 586: 4017-4027, 2008.

104. Uslua BA, Tasalb I, Gulyuza F, Sendagb S, Ucarc O, Goericke-Peschd S, Wehrendd A. Effects of oestrus synchronisation using melatonin and norgestomet implants followed by eCG injection upon reproductive traits of fat-tailed Morkaraman ewes during suckling, anoestrus season. Small Rum. Res. 108: 102-106, 2012.

105. Vanecek J, Sugden D, Weller JL, Klein DC. Atypical synergistic $\alpha_{1}$ - and $\beta$-adrenergic regulation of adenosine $3^{\prime}, 5^{\prime}$-monophosphate and guanosine $3^{\prime}, 5^{\prime}$-monophosphate in rat pinealocytes. Endocrinology. 116: 2167-2173, 1985.

106. Voet D, Voet JG. 2004. Biochemistry. $3^{\text {rd }}$ ed. John Wiley and Sons, Inc. Hoboken NJ.

107. Vonnahme KA. How the maternal environment impacts fetal and placental development: implications for livestock production. Anim. Reprod. 9: 789-797, 2012. 
108. Yellon SM, Longo LD. Effect of maternal pinealectomy and reverse photoperiod on the circadian melatonin rhythm in the sheep and fetus during the last trimester of pregnancy. Biol. Reprod. 39: 1093-1099, 1988.

109. Vosatka RJ, Hassoun PM, Harvey-Wilkes KB. Dietary L-arginine prevents fetal growth restriction in rats. Am. J. Obstet. Gynecol. 178: 242-246, 1998.

110. Wallace JM, Aitken RP, Cheyne MA. Nutrient partitioning and fetal growth in rapidly growing adolescent ewes. J. Reprod. Fertil. 107: 183-190, 1996.

111. Wallace JM, Aitken RP, Milne JS, Hay WW. Nutritionally mediated placental growth restriction in the growing adolescent: consequences for the fetus. Biol. Reprod. 71: 10551062, 2004.

112. Wallace JM, Bourke DA, Aitken RP, Leitch N, Hay WW Jr. Blood flows and nutrient uptakes in growth restricted pregnancies induced by over nourishing adolescent sheep. Am. J. Physiol. Regul. Integr. Comp. Physiol. 282: R1027-R1036, 2002.

113. Wallace JM, Bourke DA, Aitken RP, Palmer RM, Da Silva P, Cruickshank M. A relationship between nutritionally mediated placental growth restriction and fetal growth, body composition, and endocrine status during late gestation in adolescent sheep. Placenta. 21: 100-108, 2000.

114. Wallace JM, Da Silva P, Aitken RP, Cheyne MA. Maternal endocrine status in relation to pregnancy outcome in rapidly growing adolescent sheep. J. Endocrinol. 155: 359-368, 1997.

115. Weaver DR, Reppert SM. Maternal melatonin communicates day length to the fetus in the Djungarian hamster. Endocrinology. 119: 2861, 1986.

116. Witt-Enderby PA, Bennett J, Jarzynka MJ, Firestine S, Melan MA. Melatonin receptors and their regulation: biochemical and structural mechanisms. Life Sci. 72: 2183-2198, 2003. 
117. Woo MMM, Tai CJ, Kang SK, Nathwani PM, Pang SF, Leung PCK. Direct action of melatonin in human granulosa-luteal cells. J. Clin. Endocrinol. Metab. 86: 4789-97, 2001.

118. Yellon SM. The influence of photoperiod on sexual maturation in the male Djungarian hamster, Phodopus sungorus. (Ph.D. Thesis). Storrs, CT: Univ. of Connecticut, 1981.

119. Yellon SM, Longo LD. Melatonin rhythms in fetal and maternal circulation during pregnancy in sheep. Am. J. Physiol. Endocrinol. Metab. 252: E799-E802, 1987.

120. Yellon SM, Longo LD. Effect of maternal pinealectomy and reverse photoperiod on the circadian melatonin rhythm in the sheep and fetus during the last trimester of pregnancy. Biol. Reprod. 39: 1093-1099, 1988.

121. Yie SM, Niles LP, Younglai EV. Melatonin receptors on human granulose cell membranes. J. Clin. Endcrinol. Metab. 80: 1747-749, 1995.

122. Yu L, Schaad N, Klein DC. Calcium potentiates cyclic AMP stimulation of pineal Nacetyltransferase (E.C. 2.3.1.87). J. Neurochem. 60: 1436-1443, 1993.

123. Zarazaga LA, Malpaux B, Bodin L, Chemineau P. The large variability in melatonin blood levels in ewes is under strong genetic influence. Am. J. Physiol. Endocrinol. Metab. 274: E607-E610, 1998. 